\title{
EREBEA
}

Revista de Humanidades

y Ciencias Sociales

NúM. 1 (2011), pp. 281-314

ISSN: 0214-0691

\section{Cerrad el pico al «Pico de oro». Fr. Hernando de Santiago, un predicador POLÍTICO EN LA España de Felipe III}

\author{
José Antonio Ollero Pina \\ Universidad de Sevilla
}

RESUMEN

La biografía del mercedario fr. Hernando de Santiago (1557-1639) constituye un ejemplo de la autonomía que podían alcanzar los predicadores en la Espańa del Siglo de Oro. Elevado a la categoría de modelo por algunos de sus contemporáneos, que lo consideraron el «Pico de oro» del arte de la predicación, sus sermones y su vida muestran, sin embargo, una realidad diferente. Santiago, protagonizó una carrera itinerante que le dio ocasión de enfrentarse con la Inquisición, la curia pontificia, la nunciatura y las autoridades de su propia religión. En este artículo se estudia su figura a partir del enfrentamiento que sostuvo con el cabildo catedralicio de Sevilla cuando puso su lengua al servicio del arzobispo don Pedro de Castro. Este incidente decidió el signo de la última parte de su vida y le convirtió definitivamente en un predicador político crítico con la política de apaciaguamiento que había practicado el duque de Lerma.

Palabras Clave

Siglo de Oro, Predicación política, Enfrentamiento religioso.

Fecha de recepción: 2 de febrero de 2011

Fecha de aceptación: 1 de marzo de 2011

\section{Abstract}

The biography of fr. Hernando de Santiago (1557-1639) is an example of autonomy that could reach the preachers in the Spain of the Golden Age. Raised to the level of the model by some of his contemporaries, who considered him the "Golden Beak" of art preaching, his sermons and his life show, however, a different reality. Santiago, starred in a touring career that gave him the occasion to face with Inquisition, the Papal Curia, the Nunciature and the authorities of their own Religion. This paper explores this figure from the confrontation he had with the Cathedral Chapter of Seville when he put his tongue at the service of Archbishop D. Pedro de Castro. This incident signed the last part of his life and finally he became a critical political preacher of appeasement's policy that the Duke of Lerma had practiced.

\section{KeYwORDS}

Spanish Golden Age, Political preaching, Religious confrontation. 

Cuando don Pedro de Castro llegó a Sevilla en 1610, procedente de Granada, para ocupar la mitra, sucediendo a Fernando Niño de Guevara, las tensiones fundamentales entre su cabildo catedral y el arzobispo, como institución, ya existían. No fueron una creación suya. En sí mismo, los enfrentamientos no se debieron a su personalidad, pero sí fue ésta, su peculiar idiosincracia, contrastada a lo largo de su extensa y compleja carrera, el factor que determinó las características de su evolución. Ya había dado muestras con creces de hasta donde podía llegar cuando su empecinada voluntad le impulsaba a actuar en pro de una causa que, como la de los mártires y los plomos del Sacromente, asumía con una certidumbre indiscutible, y pretendía gobernar con arreglo a sus convicciones. ${ }^{1}$ La misma fuerza que le llevó a sostener el inmaculismo exaltado que se levantaría en la ciudad en 1615 y a encabezar con pasión la "guerra mariana». ${ }^{2}$ La concepción que tenía de su autoridad como pastor no desentonaba con la interpretación episcopalista de los cánones tridentinos y ello le llevó de modo inevitable a chocar con sus prebendados desde el inicio de su pontificado. De los muchos enfrentamientos que sostuvo con su cabildo, el de las coadjutorías de las prebendas catedralicias, una argucia canónica que implicaba la disminución de su jurisdicción como arzobispo, coincidió en el tiempo con el inicio de la campaña inmaculista. Durante la cuaresma de 1615, en concreto el 20 y el 30 de marzo sucesivamente, subieron al púlpito de la catedral de Sevilla el mercedario fr. Hernando de Santiago y el doctor Álvaro Pizaño Palacios, canónigo de Escritura de la Iglesia de Córdoba, un personaje que dejaremos momentáneamente al margen. Ambos predicadores trataron ese mismo tema que venía inquietando al cabildo y originando discordancias entre sus miembros.

1 Los plomos del Sacomonte han originado una ingente bibliografía en los últimos años y, en consecuencia, han dado lugar a la ampliación de la investigación sobre su máximo instigador, don Pedro de Castro. Considerando el objetivo de este artículo, reduzco las referencias a Diego Nicolás HEREDIA BARNUEVO, Mistico Ramillete. Vida de D. Pedro de Castro, fundador del Sacromonte, estudio preliminar de Manuel BARRIOS AGUILERA, Granada, 1998, y Manuel BARRIOS AGUILERA y Mercedes GARCÍA-ARENAL, eds., Los Plomos del Sacromonte. Invención y tesoro, Valencia, 2006. Aunque todos las colaboraciones de este libro tienen relación con don Pedro, la más pertinente para situar al personaje es la de Manuel BARRIOS AGUILERA, «Pedro de Castro y los Plomos del Sacromonte: invención y paradoja. Una aproximación crítica», 17-50.

2 José Antonio OLLERO PINA, «Sine labe concepta: conflictos eclesiásticos e ideológicos en la Sevilla de principios del siglo XVII», en Carlos Alberto GONZÁLEZ SÁNCHEZ y Enriqueta VILA VILAR (compiladores), Grafias del imaginario. Representaciones culturales en España y América (siglos XVI y XVIII), México, 2003, 301- 335. 
Tanto Santiago como Pizaño predicarían en el sentido que Castro deseaba y, consecuentemente, los dos provocaron idéntica indignación entre sus oyentes. Aunque no se conoce el texto de sus sermones, es fácilmente imaginable su contenido a juzgar por sus consecuencias. El martes 31 de marzo, un día después de que el canónigo de Córdoba hubiese predicado, Lorenzo Hamon, como mayordomo del comunal, y que era, precisamente, mediorracionero coadjutor, ${ }^{3}$ requirió al cabildo que gestionase que los dos osados no volviesen a predicar más en la catedral, "pues no es justo que los predicadores que suuieren en aquel puesto traten en tan particular y en general desacreditar la buena opinión en que vuestra señoría está, cosa que pareçe mal a todo el mundo", ni tolerable "la libertad con que abló [Pizaño] en lugar tan graue como el del púlpito desta Santa Yglesia, donde no se an arrojado otros mayores y más ejemplares predicadores en reprehender y sin el escándalo y descortesía de que an usado estos dos predicadores hablando mal, así de particulares como de la suprema caueça de la Yglesia”. Según el requerimiento, ambos habían actuado concertados. El domingo anterior habían comido y cenado juntos para preparar el sermón del lunes. La herida recibida era mayor porque tanto uno como otro eran personas cuya reputación moral no parecía ejemplar. Santiago era "hombre de la vida que tan sauida es". Y se lamentaba que reprimendas tan escandalosas vinieran, no de "honbres de vida ynculpable, sino por quien la haçe fuera de su gremio, obligaçiones y residençia, si bien premitida de sus comunidades por tener paz y menos alborotos en este santo tiempo de Quaresma”. Había, por consiguiente, que pedir al Nuncio que enviase juez que conociese el caso y escribir al obispo y al cabildo de Córdoba para que Pizaño se fuese "a residir a su yglesia y no nos alborote la nuestra, ni dé motiuo a tantos herejes como en este lugar ay para que hagan toma (sic) de personas tan calificadas, así en letras como en virtud y nobleça". ${ }^{4}$

El cabildo tomó las decisiones pertinentes tal como su mayordomo le requirió. En otra ocasión, tal como he indicado, veremos qué camino se siguió con Pizaño; respecto al maestro Santiago los capitulares se pertrecharon para denunciar su sermón al Nuncio, acusándole de haber predicado contra la potestad pontificia "proposiciones ynciertas y atreuidas". Por supuesto, ordenaron además, en previsión

3 El licenciado Lorenzo Hamon no era prebendado titular sino tan sólo coadjutor del mediorracionero Juan Jordán Gallo. Había tomado posesión el 31 de agosto de 1609, después de la presentación de las bulas de la coadjutoría el 20 de julio anterior y tras haber superado sus pruebas de limpieza, ACS [Archivo Catedral de Sevilla], AACC [Actas Capitulares] in sacris, lib. 242, ff. $171 \mathrm{v}$ y 173 . Hamon era natural de Jerez pero de familia inglesa y galesa de mercaderes por tres de sus cuatro costados que, según los testigos de su información, se habían instalado en aquella ciudad antes del cisma, ib., Secretaría, Pruebas, L. 12. 1609. El 7 de diciembre de 1626 tomó posesión de una capellanía real y moriría en julio de 1632, ocho años antes que el titular de la ración de la que era coadjutor, Archivo de la Capilla Real de Sevilla, Libro de Entradas, f. 22.

4 Cabildo, 31 de marzo de 1615, ACS, AACC, lib. 48, ff. 18v-19v. 
de males mayores, que se le impidiera que volviera a subir al púlpito y remitieron una comisión al arzobispo para suplicarle que ninguno de los dos predicase más en la catedral. ${ }^{5}$ De la respuesta que dio don Pedro a la petición de sus prebendados no tenemos más noticia que la que procede del «Memorial de las cosas que ay en el Arçobispado dignas de reformación» ${ }^{6}$. Este papel, que describe un panorama desastroso del estado del gobierno de la diócesis, debió pertenecer al doctor Francisco de Balza, antiguo secretario del cardenal Niño de Guevara, al que debió su provisión, en 1603, en la canonjía penitenciaria, y es incluso posible que él mismo fuera su autor. Fuera quien fuese quien lo escribió, está claro que fue obra de un miembro del cabildo catedral enemigo del arzobispo que recogía en gran medida las razones del descontento contra las maneras en que ejercía su autoridad. La coincidencia de sus críticas con la acción capitular que siguió a los sermones le presta toda verosimilitud. El mercedario era presentado como un fraile vagante, libre de toda disciplina y sin escrúpulos, que estaba al servicio de don Pedro:

"Siendo el púlpito de la Santa Yglesia de los más graues de la christiandad, donde siempre an predicado personas doctas y exemplares, y este tiempo es muçho más necessario que en los pasados por concurrir a los sermones que en él se predican muçhos estrangeros herejes y algunos dellos doctos en sus sectas, combidó para una feria de la quaresma de 1615 a un frayle a quien pocos ańos antes su general le había quitado el hábito y expelido de la orden y que actualmente viuía y viue aora fuera de clausura y obediençia, el qual a dado tan mal exemplo a todo el mundo con su desconcertada vida que a sido preso y castigado por muy atrozes y feos delictos. A éste encomendó los sermones para que, como atreuido y persona que no tiene honra que perder, dixese muchas libertades, que más fueron libelos infamatorios que reprehensiones para reformaçión de costumbres, y como ignorante, que así lo tiene confessado para su descargo en el Tribunal de la Santa Inquisiçión, palabras temerarias y malsonantes contra la potestad de la Santa Sede Apostólica. Y habiéndosele lleuado al Arçobispo recaudo del cabildo por sus diputados, lastimándose muçho que en su presençia hubiese hablado tan descompuestamente, para que lo mandase castigar, respondió que no le había parezido mal y que lo mismo se dixera él, que es buen testimonio de que el predicarlo había sido con su orden y sabiduría. $\mathrm{Y}$ a este frayle, que su orden no lo pudo suffrir por sus grandes desórdenes y de Madrid y de Roma lo an hechado por su mala lengua y yntentos y ynsolente libertad, en casa del Arçobispo a hallado buena acogida y lo tiene por su consejero, malsinando y fiscaleando a todos los que entiende que no está con ellos bien el Arcobispo, y por esto le da ayuda de costa"7.

5 Cabildo, 1 de abril de 1615, ib., ff. 19v-20.

6 ACS, FHG, Caj. 107, 19.

7 "Memorial...". 
La desconcertante respuesta de Castro a los capitulares comisionados no dejaba lugar a dudas sobre cuáles eran sus intenciones y sobre la estrecha vinculación con él de aquellos dos que, con el propósito evidente de aleccionarlos, habían subido al púlpito. El cabildo tendría elementos de juicio suficientes para calificar con términos tan duros la personalidad y las costumbres del fraile. Ciertamente, fr. Hernando de Santiago, alias "Pico de oro», sobrenombre que había ganado gracias a su habilidad retórica, no era ningún desconocido en su Sevilla natal ni en otros ámbitos más lejanos y elevados. Francisco Pacheco también nos ha legado su retrato, junto con el de otros predicadores de su generación, y con él una excelsa biografía en la que se han esfumado todos los aspectos oscuros de su vida. Al fin y al cabo un ilustre y memorable varón más. Una firme cabeza de un hombre, con la edad que debía tener hacia 1615, asentada sobre el busto de un mercedario, levemente ladeada hacia la izquierda con objeto de agraciarle con una mirada enérgica y amplia en consonancia con una frente despejada por la calvicie. La prominente nariz pende sobre una boca de respetable tamaño, ideal para vocear, perfilada con un fino labio superior. ${ }^{8}$ Porque, mal que les pesara a los capitulares de la catedral, Santiago fue un hombre afortunado en cuanto a la transmisión de su imagen a la posteridad. La efigie que le hiciera el pintor inmaculista puede compararse con el retrato de cuerpo entero que pintara Zurbarán hacia 1630-1634 para la sala de Láminas de la casa grande de la Merced calzada de Sevilla. No es cosa baladí, porque de esta manera el fraile predicador se alinea en pie de igualdad con los santos y los doctores de la Orden a la que pertenecía, signo del aprecio y prestigio que alcanzó ya en vida, al menos entre sus hermanos conventuales sevillanos. ${ }^{9}$ Fr. Juan Guerrero, uno de ellos, respetando las exigencias prosopógráficas y etopéyicas clásicas, lo describió de esta manera: "alta estatura la de su cuerpo, no de muchas carnes, el rostro moreno, con algún género de ferocidad en él, aunque tratado era muy afable y comunicable. Era liberal y dadivoso, aunque mudable e inconstante, de donde se le originaron sus inquietudes. Era de grande ánimo y de intrépido corazón. No le humillaron los rigurosos contrastes de la fortuna. En medio de lo más riguroso de ella hablaba con maravilloso desahogo. Perdió nuestra religión sagrada uno de los mejores hijos, que ha tenido en ella, y la Iglesia católica uno de los mayores predicadores desde el tiempo de los Apóstoles al siglo presente". ${ }^{10} \mathrm{El}$ fr. Hernando de Santiago de Zurbarán es el mismo hombre que dibujara Pacheco, sólo que la figura

8 Francisco PACHECO, Libro de Descripción de verdaderos retratos de ilustres y memorables varones, ed. de Pedro M. PIŃERO y Rogelio REYES, Sevilla, 1985, 73-77.

9 José FERNÁNDEZ LÓPEZ, Programas iconográficos de la pintura barroca sevillana del siglo XVII, Sevilla, Universidad, 1991, 200-202. El cuadro está hoy en la Real Academia de San Fernando en Madrid.

10 Fr. Juan Guerrero, Fragmentos históricos de la Merced de Andalucía, 1650, BN, ms. 8293, citado por Quintín PÉREZ, S.J., Fr. Hernando de Santiago, predicador del Siglo de Oro (1575-1639), Madrid, C.S.I.C., Revista de Filología Española. Anejo XLIII, 1949, 173. 
está más avejentada, mira hacia la derecha en lugar de hacerlo hacia la izquierda, el rostro ha adelgazado notablemente, la nariz es más fina. ${ }^{11}$ Respondiendo al modelo convencional de la serie pictórica, apoya un libro abierto en la mano izquierda, a la altura de la cintura, y con la mano derecha sostiene una pluma que posa sobre la hoja. El pintor le ha sorprendido en el momento de escribir y por eso mira al espectador. La serenidad y la seguridad en sí mismo que transmite y por tanto de ejemplaridad, una idea que sorprendería, y hasta repugnaría, a los prebendados catedralicios apenas unos años antes, no se corresponde en absoluto con la del fraile ignorante, delincuente, malsín e insolente de la cuaresma de 1615.

Por fortuna, los juicios del autor del memorial y de Pacheco pueden ser contrastados porque Santiago fue biografiado por sus hermanos de religión y ha merecido la atención de estudiosos contemporáneos que se han preocupado tanto de señalar los hitos de vida como de apreciar las calidades de su arte en la predicación. Para Pacheco, Santiago, al que hace nacer en 1557, era, como no podía ser menos, "de conocida calidad i nobleza" y "desde niño dio raras muestras de gran predicador por su natural eloquencia i facundia en la lengua”, dando a conocer muy pronto sus facultades entre sus paisanos. Así que bien temprano comenzaría a justificar el versículo del Eclesiástico con que coronó el marco de su retrato. ${ }^{12} \mathrm{El}$ pintor literato nos introduce de este modo en el legendario del fraile mercedario cuyos secretos resulta tan entretenido descubrir. Vale admitir que fuese cierto que cursase con gran brillantez gramática y retórica, estudios que, siguió en realidad en el colegio de la Compañía, y parece que puede confirmarse que tomó el hábito con 17 años en el convento sevillano de la Merced para seguir en los generales conventuales las artes y la teología. ${ }^{13}$ Aunque es posible que Santiago pasara también por las aulas de la Universidad de Maese Rodrigo antes de su ingreso en religión, ${ }^{14}$ se hace difícil aceptar que compatibilizara en Salamanca estudios de leyes, cánones y teología, si bien sería factible que adquiriera el bachillerato teológico en la Universidad de Valladolid en 1587 sin haber cursado siquiera. ${ }^{15}$

11 Según Pacheco, Santiago "entró en Sevilla por junio del año de 1631 a ser rector de San Laureano", Libro de descripción, 77. El retrato de Zurbarán debió ser pintado después.

12 "Dedit ei Deus linguam mercedem suam". Eclo., 51, 30: "El Señor me dio en recompensa el don de la palabra, y con ella le alabaré".

13 El dato de la toma de hábito, el 15 de agosto de 1575, en Felipe CORTINES Y MURUBE, "Pluma y lengua de Hernando de Santiago», Archivo Hispalense, 2a época, no 2 (1943), 27-77, en p. 49.

14 Hubo un Fernando de Santiago, natural de Sevilla, que se matriculó en cánones y en artes en la Universidad de Sevilla el 16 de enero y el 8 de octubre de 1574, respectivamente, A.H.U.S., lib. 480, s.f. Es posible que se trate del fraile. Otro Fernando de Santiago, nacido en Cumbres Mayores, se graduó de bachiller en artes en 1568 (16 de mayo), ib., lib. 619, 96. Después se matriculó en teología durante cuatro cursos seguidos desde 1569 a 1573, antes de bachillerarse en esta facultad, siendo ya presbítero, en 1574 (26 de julio), ib., lib. 480 y lib. 620, 52.

15 El bachillerato en Teología, 18 de junio de 1587, en F. CORTINES, art. cit., 52, 60. 
Las estancias del fraile en Madrid y las dos ocasiones en las que entró en contacto con Felipe II de las que habla Pacheco fueron también recogidas por los cronistas de la orden mercedaria. En la primera situaron la predicación del sermón motivo de las rogativas por las paces con Inglaterra que, según todos ellos, le valdría el apelativo de "Pico de oro» con que el monarca lo bautizó y con el que iba a ser conocido el resto de su vida. Desde luego, fuese cuáles fuesen las razones auténticas, los elogios desmedidos de extraordinario, asombroso y admirable le acompañarían allá por donde fuese abriendo la boca, los recurrentes tópicos de la historiografía contrarreformista de órdenes religiosas que han pervivido en sus continuadores contemporáneos. ${ }^{16} \mathrm{El}$ hecho es que Santiago desarrolló su carrera de oficios dentro de su religión a partir de 1588 cuando se cita ya como presentado, paso previo a la titulación de maestro con que es designado desde cinco años después en el capítulo general mercedario de Calatayud en que actuó como secretario. Pero es también desde entonces que inicia su implicación y las tomas apasionadas de partido que le caracterizaron en las luchas internas que desgarraban a la Merced. En 1590, siendo comendador del monasterio de Córdoba durante unos meses, fue enviado a Roma por el provincial de Andalucía inmerso en uno de estos conflictos, para regresar por orden real al año siguiente y pasar por primera vez una temporada de reclusión en un convento. Quintín Pérez, al que seguimos, afirma, no obstante, que el decenio de 1590-1600, que discurrió en un periplo constante que le llevó sucesivamente a Sevilla, Zaragoza y Málaga, fue "el más fecundo de su vida" ${ }^{17}$ En parte se sabe de sus viajes porque el mismo Santiago se preocupó de airearlos en las ediciones de sus sermones, aunque la anécdota del sermón sobre la Purificación de la Virgen que el fraile tuvo que improvisar ante un Felipe II enfermo y yacente en la cama "apretado de la gota”, estando presentes el arzobispo de Toledo García de Loaysa y otros grandes, no se debe a él sino a sus biógrafos. Elaborada a mayor gloria del mercedario, como efecto de esta demostración máxima de su pericia oratoria, se pone en labios del regio enfermo "que jamás avía tenido ora de más descanso i gusto en recompensa de los dolores que avía padecido con la gota”. Si el hecho en sí fuera cierto, hubo de producirse cuando Loaysa era administrador de Toledo por el archiduque Alberto de Austria, es decir, entre 1595-1598, porque hasta agosto de este último año no fue nombrado arzobispo, un mes antes del fallecimiento del rey, y fr. Hernando estaba predicando en Málaga ante los dos cabildos en las

16 El recorrido biográfico en el artículo citado de F. Cortines y sobre todo en el libro citado de Quintín PÉREZ, S.J. Sin desprenderse de semejante inspiración de época, el segundo al menos se distancia en sus juicios del tono hagiográfico y apologético del primero. Félix Herrero Salgado llega a decir que Q. Pérez "es severo con un orador a quien Felipe II llamó "Pico de Oro" y Paulo V "Armonía de la Iglesia", La oratoria sagrada en los siglos XVI y XVII, Madrid, 1996, I, 52.

17 Q. PÉREZ, op. cit., 35-40. Más entusiasta, para Cortines deslumbró en estos años estas mismas ciudades más Salamanca. 
honras fúnebres que se celebraron por el mismo a los pocos días después de la muerte del monarca.

Este sermón figuraría desde su publicación en el elenco digno de admiración de su producción pero la verdad es que fr. Hernando de Santiago no se dejó impresionar mucho por Felipe II. Tampoco puede presumirse que esta pieza justifique las extraordinarias dotes que se le asignan. En ella adoptaba ya el tópico esquema discursivo aprendido en la escuela que se encuentra en todas las suyas: exordio, paráfrasis y explicación del tema escogido, en este caso los versículos 16 y 17 del Salmo 32, ${ }^{18}$ y una serie de consideraciones, que este caso fueron cinco. Que debió gustar tan larga disertación a sus oyentes y a él mismo es indudable porque fue editado varias veces. La impresión de la primera, que dedicara al marqués de Priego, fue costeada por el cabildo catedral malagueño. La segunda se encuentra en la bien conocida recopilación de los sermones que se pronunciaron en los funerales del rey que publicara Juan Íñiguez de Lequerica tres años más tarde. ${ }^{19}$ Pero no por eso deja de sorprender tanto su contenido como las razones de su éxito. Santiago apenas se entretuvo en mencionar al monarca, se evadió del tema y dedicó varias páginas, lo que supone un buen rato de perorata, a cosas tan peregrinas como a comentar el valor médico y nutritivo de las lentejas y las habas. Hasta Quintín Pérez, que, siendo justos, sabía detectar los rasgos excesivos del estilo oratorio del fraile aún comparándolos con los colegas de púlpito de su tiempo, llama la atención sobre esta singular digresión retórica de una importuna "monografía sobre las lentejas y sus propiedades" ${ }^{20} \mathrm{Ni}$ siquiera tal apología vegetariana la continuaba fr. Hernando con la del regio difunto. A lo más que llegaba es a lamentarse, en la senda completamente tradicional del «menosprecio de Corte», de "los trabajos del que sigue la Corte y sirue a un gran

18 "Non saluator Rex per multam virtutem, et gigas non saluabitur in multitudine virtutis suae. Fallax equs ad salutem, in abundantia autem virtutis suae non saluabitur" (en la traducción de la Nácar-Colunga: "No es la muchedumbre de los ejércitos la que salva al rey, / ni se salva el guerrero por su gran robustez. / Vano es para la salvación el caballo; / su gran vigor no librará al jinete.")

19 La primera edición: Sermón en las honras que hizieron los Cabildos de la Iglesia y Ciudad de Málaga al rey don Philippe segundo nuestro señor, que está en el cielo. Imprimiolo el Deán y Cabildo sede vacante de la Sancta Iglesia de Málaga. Dedicado a Don Pedro Fernández de Córdova, Marqués de Priego, Señor de la casa de Aguilar. Predicado por el Padre Maestro fr. Hernando de Sanctiago, de la Orden de Nuestra Señora de la Merced Redempción de Captivos, Sevilla, Clemente Hidalgo, 1598. La segunda en Juan ÍNIGUEZ DE LEQUERICA, Sermones funerales en las honras del Rey nuestro Señor don Felipe II con el que se predicó en las de la serenissima Infanta don Catalina Duquessa de Saboya. Recogidos por Iuan Íniguez de Lequerica, impresor de libros, Madrid, Herederos de Iuan Íñiguez de Lequerica, 1601, ff. 184-204. Las referencias bibliográficas de las obras de Santiago en P. Gumersindo PLACER LÓPEZ, Bibliografía Mercedaria, Madrid, 1968, II, 807-813.

20 Q. PÉREZ, op. cit., 126. Herrero Salgado, más comprensivo y generoso con el fraile cree, que la inclusión de "un pequeño tratado sobre las lentejas" no se puede comprender en "un predicador de tanta fama y seriedad como Fray Hernando de Santiago", si no se trata de una adición posterior al sermón predicado, op. cit., 126-127. 
Prínçipe de cerca", adornándose con indicaciones morales no menos tópicas. En su invocación final pedía a Dios que el hijo, Felipe III, fuese como el padre, pero éste sólo había aparecido como gran defensor de la Fe y de la Iglesia sin que hubiese concretado en qué consistió tal cosa. Hay silencios clamorosos. Tal vez este sermón sea más notable por lo que calla que por lo que dice. Nuestro fraile fue un predicador político y, desde luego, no se caracterizaría nunca por la posesión de un espíritu timorato ni por su prudencia. Además, la modestia no era una de sus virtudes. Santiago tenía un gran concepto de sí mismo y de su valía como predicador, que no disminuyó en nada el retraso con que vieron la luz sus primeras publicaciones impresas.

Las Consideraciones sobre los Evangelios de los Domingos y Ferias de la Quaresma fueron editadas en Salamanca por primera vez en 1597, y de inmediato le siguieron tres reimpresiones hasta la de Valladolid de $1606 .{ }^{21}$ Alcanzó, pues, una cierta difusión que fue frenada probablemente porque no soportó la competencia de otras obras concionatorias que cubrían el mismo campo, a lo que hay que añadir que entre la primera y la última publicación Santiago tuvo que vérselas con los inquisidores. ${ }^{22}$ Fue a esta relación con el Santo Oficio a la que debió referirse con tanta malevolencia el autor del citado «Memorial», más que a que, ciertamente, la obra hubiese llamado la atención de los pacatos censores inquisitoriales del Índice de 1612, entre los que se contaba el jesuita P. Juan de Pineda, asustados por sus

21 Manejo la de Fr. Hernando de SANTIAGO, Consideraciones sobre todos los Evangelios de los Domingos y Ferias de la Quaresma. Compuestas por el P. M. F. Hernando de Santiago, del Orden de N.S. de la Merced Redempción de Captiuos. Aora nuevamente impressas, y reformadas en esta tercera impressión, Valladolid, Luis Sánchez, 1606. Para la ediciones anteriores de Salamanca (1597), Lisboa (1598), Madrid (1599) y la edición francesa de 1617 y de nuevo de Lisboa de ese año véase G. PLACER LÓPEZ, op. cit., ib. En las de 1599 y 1606 Santiago reeditó su sermón por Felipe II. Sobre la elección del término consideraciones para la publicación de una colección de sermones, citando precisamente a Santiago, véase Hilary Dansey SMITH, Preaching in the Spanish Golden Age. A Study of Some Preachers of the Reign of Philip III, Oxford, 1978, 42.

22 La referencia más directa a la apertura de un proceso por la Inquisición a las Consideraciones sobre todos los evangelios de la Cuaresma de fr. Hernando de Santiago en Alvaro HUERGA, Historia de los alumbrados. IV. Los alumbrados de Sevilla (1605-1630), Madrid, 1988, 139. El mismo autor recoge noticias de la correspondencia del Santo Oficio. El Consejo al tribunal de Sevilla, 12 julio 1601 (AHN., Inq., lib. 584, f. 112r.): "Aquí se ha visto el proceso causado en ese Santo Oficio contra fray Hernando de Santiago, de la Orden de la Merced, y se os vuelve con ésta lo acordado por el Consejo, como veréis señores, por lo que al fin de él va asentado: aquello se executará. / Y porque se han ofrecido ciertas dudas sobre el orden que tuvisteis de proceder fuera del común estilo de la Inquisición, ha parecido advertiros de lo que sobre esto se ha notado en el dicho proceso, para que con mucha brevedad nos deis cuenta y razón de lo que tuvisteis para hacerlo así, por la novedad que nos ha causado, y más en proceso de tanta importancia", ib., 148 n. 9. "Con ésta se os envían dos pliegos impresos de las enmiendas que por mandado del Consejo se han hecho en el libro de fray Hernando de Santiago, de la Orden de la Merced, intitulado Consideraciones sobre todos los evangelios de la Cuaresma, de la impresión de Salamanca del año de[15]97, y de Madrid del de [15]99” (AHN., Inq., lib. 584, f. 322r."), ib. 
excesos verbales que no por lejanísimos deslices teológicos. ${ }^{23}$ Pero en su momento este voluminoso libro de más de mil páginas en cuarto superó sin dificultades los requisitos de rigor, habiendo recibido el mismo ańo de su impresión la licencia del general de la Merced, que no era otro que fr. Francisco Zumel, el catedrático de la Universidad salmantina, su más prestigioso teólogo. ${ }^{24}$ Además, le convertiría en verdad en una autoridad de referencia en el arte de la predicación, comparable como arquetipo a ojos de Baltasar Gracián nada menos que a fr. Pedro de Valderrama y Hortensio Félix Paravicino. ${ }^{25}$ En la dedicatoria al marqués de Priego, Santiago se asiste con lo que en su caso se convertiría en un lugar común, las referencias a las persecuciones a la que se había visto sometido que había de entender el lector avisado, mientras que en el prólogo explicaría "las razones que me han mouido" a publicar las predicaciones de cuaresma que había expectorado en la misma ciudad universitaria. La exposición ha llamado la atención de los especialistas porque hay que reconocer que pocas veces otros predicadores supieron explicitar unas "razones" que todos compartían. ${ }^{26}$ La primera es -decía- "considerar la diferencia que ay de la pluma a la lengua, para no esperar que ha de ser todo

23 Angel Alcalá cita el expurgo de la obra en el Índice de 1612 como ejemplo de "mero escrúpulo simihistérico" junto con otros casos. Se le hicieron, según este autor, "correcciones curiosas que delatan la resistencia del Santo Oficio al incipiente barroquismo paganizante en la predicación, rebrote de pésimas costumbres renacentistas; por ejemplo, poner «Señor» en vez de «Divino Mercurio», y para evitar complicaciones políticas, escribir «capitán» en vez de «un día un Rey tirano»...", en Joaquín PÉREZ VILLANUEVA y Bartolomé ESCANDELL BONET, Historia de la Inquisición en España y América. I. El conocimiento científico y el proceso histórico de la Institución (1478-1834), Madrid, 1984, 816. En el Index Librorum prohibitorum et expurgatorum Illustrissimi ac Reverendissimi don don Bernardi de Sandoval et Roxas..., Madrid, 1612, el expurgo de la edición de 1597 de las primeras Consideraciones ocupa las páginas 430-435. Siendo adecuado el juicio de Alcalá, hay que reconocer que el libro fue leído con lupa. Los calificadores se entretuvieron en hacer correcciones menores, pero numerosas, que afectaban a calificativos, adverbios, descripciones, y se cebaron con sustituciones de palabras por matices semánticos como el indicado, quitar "esperar" y poner "presumir", cambiar "reniega" por "niega" en la frase "El día que San Pedro reniega", o con formas verbales, así el gerundio "celebrando" debía ser reemplazado por "celebra". En contadas ocasiones se observa la intolerancia ante algún elemento paganizante que parece más bien un abuso retórico. Uno evidente es un párrafo en que el fraile habla de "nuestra madre la tierra" en confrontación con la "mejor madre", la Virgen. Por supuesto, la indicación de la tierra como madre debía desaparecer. El ejemplar que utilizo (Valladolid, 1606) ya había sido impreso conteniendo la mayoría de la correcciones que figurarán en el Índice de 1612 y un tal fr. Pedro Girón, en el monasterio cartujo de Las Cuevas de Sevilla el 28 de junio de 1613, se limitó a tachar las nuevas, que tocaban al prólogo y las primeras "Consideraciones", las del miércoles de Ceniza. Por esta razón supongo que fue antes de 1606 cuando Santiago se vio ante los inquisidores. El motivo real nos es desconocido.

24 Cf. P. Fr. Guillermo VAZQUEZ NUÑEZ, «El P. Francisco Zumel (1540-1607), General de la Merced y catedrático de Salamanca», Revista de Archivos, Bibliotecas y Museos, XXXIX (1918), 53-57; 237-266.

25 A este respecto, Hilary Dansey SMITH, «Baltasar Gracián’s Preachers: Sermon-Sources in the Agudeza», Bulletin of Hispanic Studies, 63:4 (1986:Oct.), 327-338.

26 Cf. Félix HERRERO SALGADO, op. cit., 136-137. 
uno, ser muy oydo tanto en la[s] Cortes de su Santidad y de su Magestad, quanto en las más insignes Uniuersidades de Espańa, Italia, y en las mayores ciudades de ambas partes, y ser en todas ellas bien recibidos mis escritos". La conciencia que tenían todos los predicadores de la distancia que separaba la pluma y la lengua, el libro y el púlpito, en realidad, de la oralidad al texto, como también sabían los profesores universitarios, le servía, por consiguiente, para la declaración retórica de modestia, que pretendía salvar con el método expositivo que adoptaba, una imposible traslación de la segunda a la primera, que para él consistía en "un breve paráphrasis con que declaro los Euangelios en la misma forma que lo haga en el púlpito (porque he pretendido que se parezcan lo más que sea possible pluma y lengua) y van, aunque con breuedad, vencidas las dificultades que se ofrecen en la letra dellos, siguiendo el camino más acompañado de los santos Doctores". ${ }^{27}$ Sería ese procedimiento el que seguiría en su sermón, también de cuaresma, en la catedral de Sevilla con un texto ofensivo para sus oyentes que está tan perdido como su escenificación gestual. Aun así, tenemos su imagen estática y de esto último sabemos algo. De elegantísimo en el púlpito lo calificaba fr. Cristóbal de Avendaño en 1629, cuando todavía vivía, ${ }^{28}$ y Rodrigo Caro, que hubo de conocerlo y asistir a sus representaciones, escribió, rotundo, "fue eficacísimo en la pronunciación, predicó con gran energía”, juicio que, siendo escueto, ya dice mucho. ${ }^{29}$ Es muy posible que, en sus años mozos, Nicolás Antonio lo viera predicar. La forma en que lo hacía comprenden los únicos párrafos que no dependen de Francisco Pacheco en el artículo que le dedicara en la Bibliotheca. Se distinguía fr. Hernando -según afirmaba el polígrafo- por su agudeza y el donaire de su ingenio, por su asombrosa facultad para arrastrar los corazones de sus oyentes desde la más exultante alegría a la tristeza mediante la manipulación a voluntad de las inflexiones de la voz y de los movimientos corporales, utilizando tanto una suave moderación como las lágrimas inesperadas. Todo un modelo de predicador en acción, con sus recursos teatrales..$^{30}$ Un estilo excesivo que, en efecto, resultaba difícil de trasladar al texto escrito, y que podía orientarse al impacto del espíritu del fiel hasta el límite del escándalo. Pero que, por lo demás, siendo abundante en los fuertes contrastes que significaban la provocación de pavores y la expectoración de chistes mordaces, en los que Santiago era experto, de los que, de acuerdo

27 Sobre esta preocupación consciente de los predicadores en la retórica concionatoria barroca y su significado, Fernando R. DE LA FLOR, «El cuerpo elocuente. Anfiteatro anatómico-fisiológico del orador sagrado", en La península metafísica. Arte, literatura y pensamiento en la España de la Contrarreforma, Madrid, 1999, 307-345.

28 La cita de fr. Cristóbal de AVENDAÑO, Otro tomo de Santos, Valladolid, 1629, de Hilary Dansey SMITH, op. cit., 48.

29 Rodrigo CARO, Varones insignes en letras naturales de la ilustrísima ciudad de Sevilla, estudio y edición de Luis Gómez Canseco, Sevilla, 1992, 111.

30 Sobre la gesticulación y el movimiento cf. Hilary Dansey SMITH, op. cit., 60-69. 
asimimo con Nicolás Antonio, muchos de ellos corrían "de boca en boca de los más cultos, aun en nuestros días" ${ }^{31}$

El segundo motivo que afirmaba fr. Hernando, siempre tan modesto, le había llevado a la edición era el convencimiento de que muchas de sus piezas oratorias habían sido copiadas del púlpito y después difundidas, mientras que a otras, que él no había creado, le habían puesto su nombre para garantizar su calidad. ${ }^{32}$ Por ello, "he consentido -escribía- que la fidelidad de la impressión dé testimonio de mis originales". Y, por último, alegaba la absoluta suficiencia de la lengua española para propagar en ella sus sermones. El tópico a esas alturas ya se había hecho clásico, pero ello no invalida que pueda calificarse su orgullo lingüístico como orgullo patriótico y político. Si en las demás naciones los autores escribían en sus lenguas propias y abandonaban la latina, mayor razón existía para defender la utilización de la española, tan válida como su Imperio. ${ }^{33} \mathrm{Su}$ uso constituía señal de la supremacía de su dominio y testimonio de la grandeza del siglo para la posteridad, según un argumento que acreditaba con la autoridad de "uno de los mayores repúblicos de nuestra edad (aunque no de nuestra nación) da muestra de la suprema autoridad forçar los súbditos a mudar lengua"; formula que encubría a Bodin pues, como se sabe, en esta capacidad consiste una de las marcas de soberanía del poder absoluto de la República. ${ }^{34}$ Sin embargo, no sería por la lectura bodiniana por donde le vendrían sus disgustos con los censores, ${ }^{35}$ sino por la proyección de esa confianza en la calidad de la lengua, hoy tan evolucionada, en la interpretación de las Escrituras, para la declaración de su estilo, como él decía,

31 "Certe illius quamplures nec decidunt quidem hodie ab ore elegantiorum", BHN, I, 389.

32 Fernando Bouza recoge algunos testimonios esclarecedores sobre la capacidad que gozaban algunos individuos de memorizar y transcribir sermones ajenos, Corre manuscrito. Una historia cultural del Siglo de Oro, Madrid, 2001, 42-43.

33 Santiago no es excepcional. Con esta expresión se alinea al lado de Bernardo de Aldrete, Quevedo y otros autores de su tiempo, Mark JOHNSTON, «Bernardo Aldrete and Sixteenth Century Historical Linguistics», Revista de estudios hispánicos, 12:3 (1978:oct.), 441-464. Se añade, por consiguiente, a "los apologistas de la lengua española", José Francisco PASTOR, Los apologistas de la lengua castellana en el siglo de oro, Madrid, 1929. Cf. Manuel ALVAR, "La lengua y la creación de las nacionalidades modernas», Revista de Filología Española, 64:3/4 (1984), 205-238. Dentro de la literatura sevillana el prólogo Francisco de Medina a las Obras de Garcilasso de la Vega con anotaciones de Fernando de Herrera (Sevilla, Alonso de la Barrera, 1580). Sobre el mismo, Stanko B. VRANICH, Francisco de Medina (1544-1615). Maestro de la escuela sevillana, Sevilla, 1997, 111-144.

34 "También se podría dezir con gran razón que es verdadera señal de suprema autoridad forçar los súbditos a mudar la lengua”, en la traducción de Gaspar de Añastro, como señal de la suprema autoridad, de Los Seis libros de la República (Turín, 1590), Los seis libros de la República traducidos en lengua francesa y enmendados católicamente por Gaspar de Añastro Isunza, edición y estudio preliminar por José Luis Bermejo Cabrero. Madrid, Centro de Estudios Constitucionales, 1992, 377.

35 Sobre la fortuna del autor francés y de la obra ante el Santo Oficio, Miguel AVILÉS FERNÁNDEZ, "La Censura Inquisitorial de "Los seis libros de la República" de Jean Bodin», Hispania Sacra, XXXVII, 76 (1985), 655-692. 
de manera que por ella "las sentencias que parecen inteligibles y destrauadas se muestren en nuestro ordinario lenguaje tan lisas, fáciles y corrientes que satisfaze el entendimiento", por su capacidad hermenéutica, para aclarar "los más delgados conceptos", y moralizadora (encarecer lo bueno y vituperar lo malo). ${ }^{36}$ Es en este aspecto donde Santiago demuestra su independencia de criterio y hasta cierta originalidad. Como otros muchos, escribía mejor cuando se liberaba de la armadura de sus amados doctores para expresarse a su albur. Es en esas ocasiones, como reconocen los que se han preocupado de él, donde su obra alcanza valor literario.

Pacheco situaba a "Pico de oro» en Roma durante los pontificados de Sixto V y de Paulo V. Era a su primera estancia a la que él mismo se refería cuando mencionaba con jactancia que había sido oído en la corte de Su Santidad, pero las anécdotas que cuenta su biógrafo acerca de su fama en Roma y de su ascendencia ante el papa como predicador se refieren a la época de este último. En la edición de Zaragoza de 1698 de su Tratado del Acto de contrición, un folleto cuya primera impresión anota Nicolás Antonio que salió en Sevilla en 1634, se le titula Vicario General de la Curia Romana de su Orden, embajador del Senado de Palermo ante el Pontífice Romano y legado de Felipe II y Felipe III ante Gregorio XV (sic) y Paulo V. ${ }^{37}$ Otra cuestión es comprobar qué significan títulos tan sonoros en la trayectoria del fraile. Que de su segunda presencia en Italia sacaría experiencias enjundiosas no hay duda, como veremos, si bien es posible que no tan gratificantes en relación al papa Borghese como quería el citado Pacheco. No se sabe gran cosa de sus movimientos antes de la segunda estancia italiana. En 1600 Santiago, como era su costumbre, estaba al servicio de uno de los dos partidos de su orden que estaban en conflicto y actuaba siguiendo los mandatos del Nuncio y del provincial de Andalucía contra el bando perdedor. Sus desplazamientos a Zaragoza y Madrid por estas fechas obedecieron al cumplimiento de esas comisiones. ${ }^{38}$ Para Quintín Pérez, el que fuese nombrado comendador de Valladolid por su general, el sevillano fr. Alonso de Monroy, en 1602, ${ }^{39}$ da pie a especular sobre un posible acercamiento de fr. Hernando al duque de Lerma, una relación que, si no existió, evidentemente intentó, como demuestra la dedicatoria de sus Consideraciones sobre los Evangelios de los Santos. Respondería además al comportamiento intrigante

36 La frase: "y pues ya nuestra lengua no es tan grossera como antiguamente, que desautorizaua y no declaraua los Textos sagrados" estaba expurgada en el Index y fue tachada por ese fr. Pedro Girón que revisó el ejemplar que utilizo.

37 Para la edición zaragozana G. PLACER LÓPEZ, ib., 812. Para la edición sevillana todos los especialistas, desde Francisco Escudero Perosso, se remiten a Nicolás Antonio.

38 F. CORTINES, art. cit., 53-54; Q. PÉREZ, op. cit., 41-43.

39 La noticia me parece dudosa. El P. Maestro fr. Juan Negrón, catedrático de Durando en la Universidad de Valladolid y comendador del convento de la Merced en la misma ciudad aprobaba el 27 de julio de 1602 la edición de Fr. Alonso de CABRERA, Tomo I de Consideraciones en los Euangelios de los domingos de Aduiento, y festiuidades que en este tiempo caen hasta el Domingo de Septuagésima, Barcelona, por Lucas Sánchez, 1609. 
y al doble juego con que se movía y que acabaría siendo bien conocido por los que calificaba de enemigos. Creo que es él el fraile llamado Santiago que hizo llegar ese mismo año al Nuncio Gimnasio un informe sobre los recursos de fuerza cuya autoría se atribuía al cardenal Niño de Guevara. Si este fraile era el mercedario, estaría entonces en Sevilla porque el escrito lo había obtenido por medio del secretario del que ya era arzobispo de la ciudad. Acerca de cómo engatusó al doctor Francisco Balza, que no otro era el secretario del cardenal, de quien ya hemos tenido noticia, nada se puede conjeturar. Quien remitió el informe no podía ser tan ingenuo que desconociera que este texto jurídico, sólo inteligible para los expertos, era suficientemente comprometedor como para agriar las relaciones de Clemente VIII con el cardenal. ${ }^{40}$ Cuando unos meses después Niño de Guevara tuvo el primer encontronazo con su cabildo, Roma le apoyaría, pero no sin que antes el papa se permitiera un comentario capcioso sobre sus opiniones originales en materia de jurisdicción. ${ }^{41}$

Hay que imaginarse, por consiguiente, a fr. Hernando de Santiago practicando una especie de nomadismo deambulatorio en los primeros años del siglo, viviendo una época plácida en cuanto a su posición dentro de su religión, con una singular proximidad al círculo del valido y disfrutando de la benevolencia de la nunciatura. La licencia de primera edición de sus Consideraciones sobre los Evangelios de los Santos la expidió fr. Alonso de Monroy, como general de la Orden, residiendo en el convento de Sevilla que estaba entonces precisamente comenzando a reedificar, el 4 de enero de 1603 y en ella cometía a dos frailes de la misma casa que viesen el libro. La aprobación está suscrita por otros dos mercedarios en Valladolid el 15 de marzo y terminó recibiendo licencia del provisor de Zaragoza el 29 de diciembre. ${ }^{42}$ El viaje a Roma en 1605 responde a esa triple circunstancia.

40 El informe llegó a manos del arzobispo Sipontino, Gimnasio, con el título de "Los excessos que parece que ay en los tribunales reales en el uso y exercitio del remedio que llaman de fuerça”. El Nuncio lo remitió al cardenal Aldobrandini desde Valladolid el14 de diciembre de 1602 escribiendo: "Quest'originale del señor Cardinale di Gueuara mi è stato dato da un fratre che si chiama Sti. Jaco. Credo che l'habbi hauuto dal suo secretario. È il discorso che quello signore hà fatto in materia della jurisdittione quando si trattaua di quella in sua presentia. Seruirà a VS Illma. per vedere quanto si faceua quà et per prepararsi quando sarà costa l'huomo che dicono voler mandare per questo effeto, et credo che nel Conseglio d'Italia habbino commesso al Regente Mainoldo che scriui sopra questa materia”. ASV, NS. 55. 445/450, f. 431. Al recibirlo, el papa hizo que se le tradujese, indicio de que le otorgó cierta importancia, y Aldobrandini respondió al nuncio desde Roma el 13 de enero felicitándolo por haberlo obtenido y asegurándole que el pontífice lo consideraría y ordenaría algo sobre la materia, ASV, NS. 331. 16.

41 El primer choque de Niño con el cabildo, en el que aquí no podemos extendernos, iniciado en marzo de 1602 y agudizado a partir de mayo de 1603, versó sobre la visita arzobispal del mismo. Clemente VIII dijo al conocerlo según escribió Aldobrandini a Gimnasio el 21 de julio "che questi sono i frutti che quel signore raccoglie dalle sue dottrine et openioni et non è marauiglia se Dio permette che ne senta hora le punture", ASV, NS. 331. 77.

42 Consideraciones sobre los Evangelios de los Santos que con mayor solemnidad celebra la Iglesia. 
Aunque el orden en que se exponga es indiferente, primero porque fue allí remitido por su paisano Monroy, habiendo sido nombrado, según dicen sus biógrafos, vicario general de Italia, Sicilia y Francia a petición del cardenal Gimnasio; y segundo porque también iba encargado por mandato real, esto es por orden de Lerma, de una misión secreta cuyo contenido se nos escapa y para cuyo desempeño, además de una recomendación al embajador, el duque de Escalona, llevaba una generosa asignación. ${ }^{43}$

Las vicisitudes de Santiago en Italia hasta su definitivo regreso en 1608 fueron historiadas por los cronistas de su religión y han sido reconstruidas modernamente por los dos autores que fundamentalmente se vienen citando de manera que resulta innecesario volver sobre ellas en todos sus detalles. Sólo apuntar que su situación cambiaría después de su elección como provincial de Italia en mayo de 1606 en un capítulo presidido por el cardenal Zapata. El giro de su suerte dependió de los luchas interiores de la Merced y de la modificación de la política real en relación a la mismas como consecuencia de esas disputas. El mismo Zapata daría testimonio amargo del escándalo y el cansancio que le producía la proliferación en Roma de frailes de diferentes obediencias y procedencias enfrentados continuamente entre ellos. ${ }^{44}$ Los conflictos de los mercedarios merecían un capítulo especial y fr. Hernando de Santiago respondía al prototipo. El juicio de Tirso de Molina, que llegó a calificarlo de natural rígido y condición intolerable, responsable por sí mismo de que se hiciera aborrecible para sus compañeros y cayeran sobre su persona innumerables querellas, parece apoyarse en el propio transcurso de sus actos. ${ }^{45}$ El cardenal Zapata tendría ocasión de irse formando la opinión que más adelante, como se verá, expresará sin paños calientes. Lo cierto es que el predicador se vio envuelto en acusaciones contra él a las que contestaba con maniobras defensivas e hizo todo lo posible por dilatar las órdenes que le llegaban de la corte y desde Roma. A despecho de las mismas, prolongó su itinerario por Sicilia y Nápoles, cosechando éxitos con sus dotes oratorias como quieren sus allegados que, pasado el tiempo, escribirían sobre él, los mismos que afirmarán

Con un breve paráfrasis y explicación de las letras de los Euangelios. Por el P.M.F. Hernando de Santiago, del Orden de N.S. de la Merced Redempción de Cautiuos. Dirigido al Duque, Marqués de Denia, Cauallerizo mayor del Rey N.S. y de su Consejo de estado, etc., Madrid, Pedro Madrigal, 1603; Zaragoza, Carlos de Lavayen, 1605. Sobre la edificación de la casa grande de la Merced de Sevilla, José FERNÁNDEZ LÓPEZ, op. cit., 163-164.

43 Para esto la carta de Felipe III al duque, Valladolid, 6 de abril de 1605, en que se ordena pagarle "con gran recato y secreto" 400 ducados "con tanto secreto que no se venga a entender que tenéis orden mía, que así procede de mi voluntad y conviene a mi servicio", publicada por Q. PÉREZ, op. cit., apéndice IV, 194.

44 Véase la cita de su memorial secreto de 1607 en J. GOÑI GAZTAMBIDE, art. "Zapata, Antonio", DHEE, IV, 2802-2805, de Q. ALDEA, Iglesia y Estado en la España del siglo XVII, Madrid, Universidad de Comillas, 1961, 219-233.

$45 \mathrm{El}$ juicio de Tirso citado por Q. Pérez, op. cit., p. 51. 
que suscitó tanto asombro su predicación en Paulo V que éste lo llamó "Armonía de la Iglesia» y exclamó aquella frase elogiosa que se le aplicaría ya para siempre, apelativo y oración que realmente poco casan con el concepto que se fueron formando los hombres de confianza de su curia. ${ }^{46}$ A fines de 1607 su elección como provincial de Italia fue anulada e inmediatamente el pontífice le mandó que abandonara Roma. ${ }^{47}$

Después de un conato de resistencia, valiéndose, al parecer, de su altos protectores, los Colonna, del que sólo cedió cuando fue aprehendido, Santiago salió despedido de Roma el 31 de enero de 1608. Cinco días después el secretario de Estado escribía al Nuncio Caraffa para prevenirle contra ese hombre "arditissimo", al que no debía honrar ni del que no tenía que fiarse. Según Q. Pérez, de quien se recoge esta carta, se inician entonces diez años en la vida de nuestro «Pico de oro» que constituyen un misterio. ${ }^{48}$ Se sabe que fue arrestado nada más comparecer en la corte y entregado a sus autoridades religiosas. Fr. Hernando reaccionó contra la expulsión de la orden a la que fue sentenciado apelando de inmediato al Nuncio. De nuevo desde Roma se remitieron a Caraffa instrucciones sobre cómo debía conducirse con un individuo del que existía una opinión universal sobre su persona y su carácter. De una forma muy eclesiástica, se le aconsejaba que fuera justo con las partes, la del general y la del fraile, pero que a éste no le venía mal la mortificación y el castigo que se le había impuesto y que se había merecido. Aún así, debía procurar exhortarle y, sobre todo, prohibirle terminantemente que fuese a Roma. El papa no quería verle por nada del mundo. ${ }^{49}$ Las mismas fuentes mercedarias no sirven de mucho para explicar cómo consiguió Santiago la readmisión y el acceso de nuevo a los oficios. Aunque algunas así lo indican, no es seguro que en 1609 ya se le hubiese confiado el puesto de comendador del convento de Granada. Su mejor biógrafo, siempre Q. Pérez, se pregunta si anduvo durante esos ańos posteriores a su expulsión temporal predicando por varias ciudades porque no lo ve reaparecer hasta que "inesperadamente se halla en 1615 excitando las iras del Secretario de Estado". ${ }^{50}$ El autor del memorial contra don Pedro de Castro no tenía ninguna duda a este respecto: ese mismo año permanecía aún expulso, privado del hábito, exclaustrado y viviendo fuera de toda obediencia. La afirmación es coherente con la intencionalidad de su alegato, pero lo que resultará indudable es que en este intervalo fr. Hernando de Santiago había pasado por Sevilla.

En enero de 1608, pese a que por esos mismos días trataba de evadirse de las amenazas que le acosaban, el fraile todavía continuaba presumiendo de vica-

46 La frase, «Panigarola delectat, Lupus movet, Toletus docet, Sanctusjacobus omnia», en F. CORTINES, art. cit., 70-71.

47 Para todo este periodo, de nuevo, Q. PÉREZ, 49-56.

$48 \mathrm{Ib} ., 153$. La carta en apéndice V, 194-195.

49 Ib., 154-157. Esta segunda carta, 27 de septiembre de 1608, en apéndice V, no 2, 195.

$50 \mathrm{Ib} ., 157$. 
rio general y provincial de las provincias mercedarias de Italia y las Galias, unas titulaciones que entonces no le correspondían, y actuaba como procurador del virrey de Sicilia don Juan Fernández Pacheco, marqués de Villena y duque de Escalona, para recoger de las catacumbas de las vías Apia y Ardeatina un buen lote de reliquias martiriales en su nombre. A principios de 1611 entregaba en Sevilla al chantre don Antonio Pimentel las reliquias de los santos y mártires Floro, Eugenio, Lucio, Felicísimo y Emerenciana. ${ }^{51}$ La primera edición de Madrid de sus Consideraciones sobre los Evangelios de los Santos, aunque con un número de correcciones sorprendentemente mucho menor que la que afectó a su anterior sermonario si se atiende a las opinión que expresó sobre la obra y el autor al menos uno de sus censores, también fue expurgada por el Index de $1612.5^{52}$ En consonancia con ello el título de la tercera y última edición, la de Salamanca de 1615, en la que se consignaba fe de erratas y tasa fechadas en julio de ese ańo, anunciaba que la obra estaba corregida y enmendada por los inquisidores de acuerdo con el Catálogo de 1613 (sic). ${ }^{53}$ Santiago mantuvo el prólogo tal cual excepto que adelantaba que estaba entonces ocupado "en sacar el Quadragesimal reformado y con tantas cosas añadidas que demás se podrá tener por un libro nueuo”. De modo que, allá donde estuviera, la modificación de las primeras Consideraciones era la tarea literaria a la que estaba dedicado cuando don Pedro de Castro lo reclamó para predicar en la catedral. Un esfuerzo que resultaría baldío porque esta revisión nunca llegaría a publicarse.

La noticia que trae Pacheco acerca de que fue llamado por don Jerónimo de Leiva, provisor de Sevilla, para valerse de su extraordinario saber jurídico no es contradictoria con los afanes que ocupaban a Santiago por aquellos días. Esa supuesta erudición en los cánones y las leyes civiles, que debe corresponderse con la asombrosa memoria que le atribuye Pacheco -"el ombre de mayor memoria que se a conocido", afirmaba-, capaz de retener páginas enteras de los libros que leía,

51 «Testimonio de las reliquias de los bienaventurados mártyres S. Floro, Eugenio, Lucio, Felicíssimo y Emerenciana, virgen y mártir», Sevilla, 7 de enero de 1611, en el que fr. Hernando de Santiago hace personalmente la entrega a Pimentel con el testimonio de la extracción de las reliquias de los cementerios de San Calixto, San Soterio y Santa Balbina, los breves otorgados al virrey, de 5 de septiembre de 1602 y 6 de noviembre de 1606, cuando era embajador ante la Santa Sede y el poder de éste, dado en Mesina, 18 de septiembre de 1607, ACS, FHG, Caj. 117, 24/2.

52 Las correcciones en Index Librorum prohibitorum, 435-436. "Y si el Padre Hernando de Santiago se le mandase que no imprimiese más y aunque no predicase, poco perdería la yglesia. V. Alteza verá en lo uno y en lo otro lo que más combiene y ordenaré lo que le pareciere será lo más açertado", opinaba el trinitario fr. Pedro de Castillo, según cita Q. PÉREZ, op. cit. 183.

53 Placer no recoge Consideraciones sobre los Evangelios de los Santos que con mayor solemnidad celebra la Iglesia. Con un breve paráfrasis y explicación de las letras de los Euangelios. Corregido y enmendado por los Señores Inquisidores, conforme el Catálogo deste último año de 1613. Por el P.M.F. Hernando de Santiago, del Orden de N.S. de la Merced Redempción de Cautiuos. Dirigido al Duque, Marqués de Denia, Cauallerizo mayor del Rey N.S. y de su Consejo de Estado, etc., Salamanca, Imprenta de Antonia Ramírez, 1615. 
explicaría su inclusión en el círculo de los familiares del arzobispo porque Santiago no era jurista, aunque, como se ha mencionado, sus biógrafos hablan de sus estudios de derecho. Además, tal vez fuese por medio de Leiva como Castro tuvo conocimiento de su existencia o, a la inversa, como vio la oportunidad de situarse al servicio del prelado. Es posible que el primero hubiese conocido a fr. Hernando de Santiago durante su estancia en Roma, a donde había ido con licencia del cabildo, entre 1605-1607, pero esto no pasa de ser una suposición porque nada se sabe de la relación que pudieran haber tenido en el pasado. ${ }^{54}$ Aunque los dos tenían exactamente la misma edad, sus carreras hasta entonces habían sido divergentes. Jerónimo de Leiva había realizado la suya bajo el paraguas protector de don Fernando Nińo de Guevara. Cuando el cardenal lo trajo a Sevilla para servirle como provisor durante los primeros meses de su prelacía, este doctor en derecho, originario de Lucena, era fiscal del Santo Oficio. Después, mientras ejerció el provisorato don Felipe de Haro, actuó como juez de la iglesia y vicario general del arzobispado hasta que en 1606 recuperó el oficio cuando este último fue designado visitador de Milán, para mantenerlo hasta la muerte de su señor. ${ }^{55}$ Lógicamente, a Niño de Guevara, que hizo que se contara entre sus albaceas, le debería también su introducción en el cabildo. ${ }^{56}$ En septiembre de 1603 los capitulares sevillanos aceptaron que fuera nombrado por el arzobispo para el canonicato que dejaba vacante con su muerte don Alonso de Ulloa, uno de los sobrinos de don Rodrigo de Castro, el prelado anterior, y, pese al litigio que le enfrentó con un Francisco de Acuña, que también la pretendía, logró conservar la prebenda y desde ella y desde su experiencia se pasaría con armas y bagajes a don Pedro de Castro. ${ }^{57}$

54 El 30 de marzo de 1605 el cabildo le concedió a Leiva seis meses de horas para ir de romería a Roma. Esta concesión, en la mayoría de los casos un trámite, se convirtió en un problema porque era familiar del cardenal Niño y existía la sospecha que su intención era defender ante la Santa Sede determinados negocios contra el mismo cabildo. El día 29 el mayordomo del comunal había requerido que los capitulares que fuesen en romería jurasen además del estatuto correspondiente, que no harían en ese tiempo negocios contra el cabildo por sí o por personas interpuestas. Los capitulares decidieron un auto en ese sentido y el 2 de abril Leiva protestó y apeló contra él, ACS, FHG, Caj. 57, 5/23. Todavía el 6 y el 10 de marzo de 1607 el cabildo discute si le concedería horas por el tiempo que estuvo en Roma sin su licencia, ib., AACC, lib. 44, f. $7 \mathrm{v}$.

55 Que nació hacia 1557 porque confiesa 46 años en el pleito que sostuvo el cardenal con el cabildo sobre las visitas de las capillas de la catedral en junio de 1603, ib., FHG, 108, 1. El primer nombramiento del cardenal Fernando Niño de Guevara de Jerónimo de Leiva como provisor, juez de la Iglesia y juez de testamentos, presentado en cabildo el 8 de octubre de 1601, ACS, AACC, lib. 42, f. 80. Felipe de Haro sería provisor como mínimo desde octubre de 1602 hasta que fue comisionado para la visita de Milán. El cabildo le dio tres ańos de horas el 27 de enero de 1606 para cumplir esta misión, ib., lib. 236, f. 242.

56 El provisor Jerónimo de Leiva figura entre los albaceas en el testamento del cardenal, Sevilla, 5 de enero de 1609, ACS, FHG, Caj. 46, 1.

57 El poder de Niño para su provisión simultánea en la canonjía que había sido de don Alonso de Ulloa de 2 de septiembre de 1603, ACS, FHG, 96, 5. El proceso con Acuña, un clérigo zamo- 
El caso de Leiva constituye otro ejemplo del magnetismo del visionario del Monte Santo. A finales del verano de 1610 el cabildo de los canónigos in sacris había decidido que volviera de nuevo a Roma, esta vez como su representante ante la curia para defenderlo en el pleito que venía sosteniendo con los racioneros. $^{58}$ Después de negociar el salario que tenía que recibir aceptó la misión que se le había confiado, pero terminó provocando la desconfianza de sus colegas según fue dilatando su partida antes de acabar desistiéndose. En marzo de 1611 los canónigos ya sabían que tendrían que elegir a otro procurador. ${ }^{59} \mathrm{La}$ causa de las dudas de Leiva, primero, y su renuncia, después, sólo puede atribuirse a su acercamiento a don Pedro. Años después, en 1618, escribiría desde Roma a otra criatura del arzobispo, su secretario, el doctor Cristóbal de Aybar, que él no tenía ninguna inclinación a ocupar oficios "ni la tenía ocho años ha quando venido el arçobispo a Seuilla fue menester rogarme mucho (como él [el arzobispo] lo ha dicho después) para que yo fuese su prouisor". ${ }^{60}$

Según su versión, en consecuencia, no se acercó él sino que lo buscó quien desde entonces se convirtió en su señor. Claro está que éste es el testimonio interesado de un hombre que hablaba de sí mismo a un tercero en otro contexto y que, desde que llegó a Sevilla, casi no había hecho otra cosa que servir cargos de prelados. En realidad, pocos meses después de esta carta, escribía a don Pedro de Castro: "que, antes de ir a Seuilla VSI, le escribí sobre ello, no sé si fue a VSI o al deán de Granada Antolínez, diçiéndole que si VSI era prelado de Seuilla 50 años, no hiçiese otra cosa sino concluir la justiçia de los curas y auerigualla en esta materia, fuera un pontificado de gran seruicio de Nuestro Señor y el más prouechoso para las almas que huuiera habido muchos siglos hauía" ${ }^{61}$ Valga como disculpa que trataba de defenderse de la acusación que el arzobispo le hacía acerca del desinterés que demostraba en la defensa de uno de sus pleitos más importantes, del de los curas y los beneficiados, pero Leiva se desmentía a sí mismo porque en esto no podía engañarle, aunque hay que reconocer que sabía bien cómo alimentar su ego. La dirección aquí es completamente la contraria: fue él quien procuró el acercamiento esperando que se le confiara el oficio. El hecho es que

rano que había obtenido bulas de provisión del arcedianato de Jerez y el canonicato que poseyera Ulloa, ante don Antonio Pimentel en abril de 1604, ib., Caj. 105, 1 (no 10).

58 El 23 de agosto de 1610, cinco días despúes de que el canónigo magistral don Manuel Sarmiento de Mendoza se hubiera desistido, el cabildo eligió a Leiva, ACS, AACC, lib. 242 in sacris, ff. $181,181 \mathrm{v}$.

59 La cuestión del salario se estuvo tratando en los cabildos de 1 y 6 de septiembre de 1610, ib., ff. $182 \mathrm{v}, 182 \mathrm{v}-183$. El 19 de enero siguiente ya se cometió al canónigo Juan Checa que inquiriera acerca de qué pensaba hacer Leiva. Éste se excusó definitivamente antes del 5 de marzo, día en que se convocó nuevo cabildo para nombrar a su sustituto, ib., lib. 244, ff. 1, 3.

60 Jerónimo de Leiva a su corresponsal, Roma, 19 de mayo de 1618, AAS, Sec. II. Gobierno. Asuntos Despachados, leg. 1 (signatura moderna 04506), R. 13/6.

61 Jerónimo de Leiva al arzobispo, Roma, 9 de agosto de 1618, ib., R. 13/29. 
en las oposiciones a la canonjía doctoral que comenzaron a celebrarse en agosto de 1611 ya se le ve haciendo las funciones de provisor, adscrito por completo a su familia. ${ }^{62}$ El puesto, cuyas atribuciones conocía tan bien, lo sostendría en sus manos durante más de dos años, ${ }^{63}$ y a partir de entonces se convertiría en una de las más fieles criaturas de Castro. A su lado fracasó en su intento de alzarse con la chantría tras el fallecimiento de don Antonio Pimentel y lograría a duras penas acceder a la tesorería después de un largo y extraño pleito, que habrá que explicar, con la criatura más querida del mismo patrono, el deán de Granada don Justino Antolínez. En 1615 Jerónimo de Leiva todavía no se ocupaba de los asuntos del arzobispo como su agente ante Paulo V, pero estaba a su servicio en otros puestos, tal vez como oficial y vicario general, y bien pudo ocurrir que llevara a Santiago ante él como escribiera Pacheco.

Pero a diferencia de otros personajes que le sirvieron intelectualmente y con el trabajo literario, la relación del mercedario con el arzobispo no se fundamentó en la exteriorización previa de su anuencia con sus convicciones teológicas y providencialistas esenciales. No parece que entre sus escritos conocidos se aluda a los santos mártires del Monte Santo granadino, lo que resulta notable en un hombre que, como se ha tenido ocasión de comprobar, reverenciaba las reliquias y viajaba con ellas. Y, sobre todo, en ninguna de sus dos Consideraciones, concebidas y construidas como sermonarios manuales, se encuentran referencias específicas a la Virgen, ni a sus misterios; ni siquiera se detiene en el punto básico del concepcionismo, el pecado original. Es seguro que sus opiniones sobre la materia mariana, en verdad muy vinculada a la tradición de su orden religiosa, ocuparía su Marial, o Sermones de Nuestra Señora, pero, según la versión más autorizada, el manuscrito de la obra se perdió cuando fue enviado de Madrid a Granada para su impresión. ${ }^{64}$ En cualquier caso, nada se sabe de la data de la elaboración de este libro desaparecido y, por otro lado, no hay noticias de que Santiago intentara rehacerlo. No obstante, todos los indicios apuntan a que si Castro hizo que Pizaño y él subieran al púlpito catedralicio para sermonear a los capitulares contra las coadjutorías, de la

62 El 24 de agosto de 1611 Leiva se presentó al cabildo como tal para sustituir al prelado en el proceso, ACS, AACC, lib. 244, f. 8.

63 El 23 de diciembre de 1613, en uno de sus requerimientos sobre la tesorería, aún se denominaba provisor. Siete días más tarde ya se titulaba como tal el doctor Bernardo de Aldrete, el erudito y sabio canónigo cordobés tan apegado al arzobispo y sus tesis, ib., ff. 105rv y ACS, FHG, FHG, Caj. 107, 19/16.

64 Según Pacheco, "escrivió 3 libros llenos de erudición y espíritu, que fueron un cuaresmal, un santoral i un marial, con fiestas de Cristo i su Madre. Este último se lo hurtaron, aviéndolo aprovado. Por si alguno lo imprimiere, su estilo publicará su autor", ed. cit., 77. Nicolás Antonio escribe sobre esta pérdida citando como fuente al arzobispo de Otranto fr. Gabriel Adarzo y Santander. Placer se limita a seguir a N. Antonio. No obstante, habría que conocer la edición francesa bajo el título: Fêtes de notre Seigneur et de la Sacrée Vierge, et les Panegyriques des Saints, París, 1617, que cita Placer, ib., no 5.853. 
misma manera tendría previsto que los dos predicasen por la causa concepcionista. En el primer programa de sermones que publicaron los hermanos nazarenos de la cofradía de la Santísima Cruz in Jerusalem se anunciaba que el ciclo de las fiestas y certámenes en honor de la Purísima Concepción lo abriría el 26 de abril de 1615, domingo de Cuasimodo, el canónigo de Escritura de Córdoba y que el lunes le seguiría el maestro mercedario, y antes de que llegara el día señalado fue "innovado el orden que se publicó en el Certamen por justas causas”. Cuáles fueran éstas, no se explicaban. Sobre ellas se hizo el silencio que comprenderían los discretos, porque no figuraban ninguno de los dos sujetos que habían protagonizado el escándalo de los prebendados. ${ }^{65}$ Lo cierto es que, cuando se iniciaron las fiestas, seguramente el inquieto Santiago ya se había visto forzado a marcharse a la corte.

El primer efecto de la reacción capitular fue, por consiguiente, que estas voces desaparecieran de los púlpitos de la ciudad durante toda la campaña inmaculista. Pero sólo fueron las voces y, después de todo, los motivos que provocaban los enfrentamientos del cabildo con su arzobispo eran otros. De hecho, los beneficiados catedralicios comenzaron a actuar antes de que Lorenzo Hamon presentara la protesta contra los imprudentes predicadores. Ya el 24 de marzo sus diputados habían remitido sendas cartas, que contenían una información y testimonios del sermón que Santiago había pronunciado hacía cuatro días, al canónigo y arcediano de Sevilla don Félix de Guzmán, su agente extraordinario en la corte real, y al chantre don Juan Antonio Zapata, que cumplía la misma misión en Roma. Pese a que se disponía de representantes permanentes en las dos capitales, ambos habían partido para sus respectivos destinos con el objeto de defender la inveterada cuestión de los «adjuntos». Ésta, que fue posiblemente la más recurrente causa de fricción entre las corporaciones catedralicias y sus obispos desde que comenzaran a aplicarse las disposiciones tridentinas, estaba viviendo desde el año anterior un rebrote conflictivo en todo el reino y lógicamente, había originado una nueva colisión con don Pedro de Castro. La decisión de enviar al chantre, aprovechando que había sido reclamado por su tío, el cardenal Zapata, se había tomado a mediados de junio de 1614, mientras que la marcha a Madrid de Guzmán, uno de sus hombres más importantes e influyentes, fue una resolución tomada por los capitulares seis meses más tarde. ${ }^{66}$ Que fueran ellos y no otros los que recibieran tal encargo no era casualidad porque ambos tenían razones más que suficientes para realizar una tarea que suponía enfrentarse con el arzobispo.

65 Las dos relaciones Juan PÉREZ DE GUZMÁN GALLO, El primer certamen poético que se celebró en España en honor de la Purísima Concepción de María, Madre de dios, Patrona de España y de la Intantería española (Sevilla, 25 de abril de 1615). Madrid, 1904.

66 Para Zapata, para que asistiese a los negocios pendientes de la Iglesia con don Tomás de Ayala en Roma, el cabildo de 16 de junio de 1614, ACS, AACC, lib. 47, f. 126v. La decisión de nombrar a don Félix de Guzmán como agente en Madrid se tomó en el cabildo de 16 de enero de 1615, ib., lib. 48, f. 3v. 
"Acabaré de instruirme en la doctrina de el Padre Santiago, y no para seguirla. Haré la diligencia con el señor nunçio con las mayores veras y a efecto que yo pudiere", respondió Guzmán brevemente al cabildo el 1 de abril, a vuelta de correo, sin tiempo de haber entrado a fondo en el asunto, tras echarle un vistazo a los papeles que le cursaron sus compañeros. Y añadió, con un deje conmiserativo, "algo reçelo la mansedumbre de Su Señoría Ilustrísima [el Nuncio], pero tanto mayor aurá de ser la justiçia”. ${ }^{67}$ Por su parte, Zapata no tuvo ocasión de abrir la correspondencia del cabildo de 24 de marzo hasta el 8 de mayo. Como era de esperar, contestó compartiendo la indignación capitular pero, más diplomático y conocedor de los entresijos de la corte pontificia, procuró a un tiempo apaciguar los ánimos. Su criterio, más precavido que el que se le recomendaba desde Sevilla, era que "auiendo considerado bien este negoçio, a parecido que por ahora no conuiene dar memorial en forma a Su Sanctidad porque, aunque es uerdad que a sido desuergüença grande la libertad con que ese fraile habló en el púlpito, no basta la informaçión hecha para que se pueda proçeder contra ese hombre con las ueras que el cabildo desea y, no auiendo de ser así, es lo mejor no començarlo. Y, si a sido negoçio tan escandaloso, el señor Nunçio está çerca y pondrá el remedio necesario".

Para reducir la impresión que la respuesta, relativamente fría y que daba pie a que fuera entendida como una evasiva, pudiera causar en sus corresponsales, el chantre concluía: "En mi poder quedan los papeles para mejor ocasión y alguna se ofreçerá en que Su Sanctidad sepa los consejeros que el señor arçobispo tiene a su lado, que éste, creo, es el prinçipal intento del cauildo y lo que más nos importa”. Y, sobre todo, los consolaba con los cuatro renglones ológrafos que su poderoso tío adjuntaba en su carta, pues "para que el Papa conozca al señor arçobispo más importará una palabra suya que todos los dichos de los testigos”, escribió Zapata a manera de posdata. En efecto, el cardenal redactaba estas palabras que, amén de respaldar a su sobrino y recordar el desprestigio que corría en Roma sobre la persona de Santiago, a quien ya había tenido ocasión de conocerlo bien, prometían finales felices a cualquier litigio que se sostuviera con Castro:

"El pico de fray Hernando de Santiago es muy conocido en esta corte y
más su trato, y assí se an admirado todos los que an entendido que el señor
arçobispo le faboresca y le dé lugar para que predique en essa Santa Yglesia.
Yo informaré dello a Su Santidad y esto bastará por ahora para que valga
en lo que adelante se tratare y crean Vs. Ms. que el chantre tiene todo el
cuydado de que deue en su seruiçio y que yo le ayudaré de muy buena
gana". ${ }^{8}$

67 La carta, original y ológrafa, en ACS, FHG, Caj. 133, 16/1.

68 Roma, 8 de mayo de 1615, ib. Recuérdese que Zapata era el cardenal protector de las iglesias españolas. Los canónigos in sacris habían nombrado el 20 de octubre de 1610 a Zapata protector del cabildo, ACS, AACC, lib. 242, f. 183v. Pero en el cabildo ordinario de 11 de octubre de 1610 
Esta respuesta no llegaría a Sevilla hasta el 1 de junio. Demasiado tarde como para influir de modo decisivo en el transcurso del proceso. Su mismo desarrollo habría hecho además innecesaria la recomendación de Zapata de que se siguiera ante el Nuncio, monseñor Antonio Caetani, y se pospusiera la vía romana. En realidad, como se verá, el cabildo tampoco prestó demasiada atención a la sugerencia y pronto acudiría a Roma. Mientras tanto, continuó fortificando el cerco del fraile encomendando una información de testigos en toda regla al prior de San Juan de Acre como comisionado de alguna de las numerosas letras apostólicas con las que podía contar. Por alguna razón este clérigo fue procediendo con tal parsimonia que la querella hubo de proseguir en principio sin ese trámite que se pensaba imprescindible para llevarla a buen puerto. En cualquier caso, don Félix de Guzmán a mediados de mayo ya había avisado desde Madrid que las cosas allí no se veían tan sencillas e inmediatas como se veían en Sevilla, y planteaba un panorama mucho más complicado que el que sus colegas imaginaban. Al cabildo, venía a afirmar, no le convenía declararse abiertamente contra fr. Hernando y por ello "se haze con la destreza y disimulación necesaria”. En fin, nada nuevo, pues éstas eran las virtudes del siglo para todo negociador que se preciara. Pero la dificultad auténtica radicaba en que "la matheria de coadjutorías está aborresida de Su Magestad y de sus ministros y todos los que trataren de defenderlas o de matheria que les toque an de dar disgusto en ello". Es decir, y el arcediano era bastante preciso en este sentido, la insistencia excesiva en procurar el castigo de Santiago sería entendida como una estrategia de defensa de las coadjutorías y daría lugar a que el gobierno se pusiera de su lado. Por ello avisaba que" como este rumor de fr. Hernando se leuantó sobre punto de coadjutorías, es fácil que se entienda las defiende quien le sigue”. La conducta que mantenía el Nuncio respecto al asunto de los adjuntos era la más adecuada y no convenía mezclarla con ese tema nuevo; así que convenía hacer lo que él, Guzmán, estaba haciendo, ayudarla "todo lo posible pero con el tiento neçessario para no incurrir en disgusto de los ministros, y prinçipalmente del duque, que tan opuesto está a las coadjutorías y tan inclinado a la conseruaçión de adjuntos. Y así conuiene mucho no dar causa para perder en todo o en parte su graçia, que es lo que más nos importa" ${ }^{69}$

Para demostrar la verdad de su análisis don Félix contaba la conversación que, durante más de una hora, había mantenido la noche anterior con el arzobispo de Capua. Éste ya había hablado con Santiago en persona y había tenido ocasión de conocer la elocuencia del mismo, según respondió a la burlona pregunta con

se había votado como tal, en lugar del fallecido cardenal Pamphilio, al cardenal Gimnasio, quien el 31 de enero siguiente respondió aceptando, ib., lib. 45, f. 92v y lib. 46, f. 6v.

69 Don Félix de Guzmán a los diputados de negocios del cabildo, Madrid, 19 de mayo de 1615, ib.. Esta carta respondía una de 12 del mismo mes. 
que el arcediano inició la entrevista. De ella puede deducirse que el fraile no estaba en Madrid por su voluntad, huyendo del incendio que había provocado o para aprestarse a defenderse, sino por disposición de su general y recluido en un convento. El Nuncio le explicó que fr. Hernando había admitido que, una vez que se le hubo notificado el mandato de su superior, "acudió a su seso"; de modo que, ateniéndose a ciertas recomendaciones y por prudencia, permitía que estuviese en la casa de su orden, "redusiéndose a esto por una razón de estado de que me dio gusto y yo no la doy a V. S. por pareçerme no es bien fiarla de carta". Ahí era nada, cómo los enunciados de un sermón se habían mezclado con los «arcana imperii».

La conducta que el prudentísimo representante pontificio pensaba seguir consistía en no tomar ninguna resolución hasta que Roma despachara instrucciones y fuera elegido un nuevo general de los mercedarios, cosa que había de tener lugar en Pentecostés. Estaba de acuerdo con la petición que le hizo don Félix de que Santiago no volviera a Sevilla; es más, aseguraba "que estaría quieto y que oy no temía a otra persona sino a Su Señoría Ilustrísima [el Nuncio]" porque sabe que cualquier movimiento suyo le disgustaría e incluso él mismo se había disgustado porque don Pedro de Castro le había escrito al presidente del Consejo en su favor. También había prometido el Nuncio que escribiría al prior de San Juan para que no dilatase la información de testigos y se limitase a examinar los nombres que el cabildo le había entregado en un memorial. Pero en tiento, discreción y prudencia el astuto arcediano no le fue a la zaga. Su intención era calmar la ira de sus compañeros, evitar que la precipitación pudiera arrumbar el negocio principal, calmarlos en suma. Juzgaba que la pretensión de que el abad Sánchez Gordillo fuera comisionado para meterle mano al fraile sería un error y "fuera una cosa que se notará mucho, ni se pudiera conseguir con el señor nunçio porque su S.I. sabe, y otros muchos no lo ygnoran, lo que passa entre el señor Arçobispo y Gordillo, y que su Señoría I. tiene en protectión a Santiago y a esta matheria”. Y, por fin, consideraba que había llegado para él la hora de regresar a Sevilla. La demostración que había hecho el cabildo resultaba más que suficiente. Estaba claro que fr. Hernando tenía miedo y no quería acrecentar dificultades: "según lo que e auisado a V.S. y lo que e entendido del miedo de Santiago y del deseo que tiene el no acrescentar dificultades, me pareçe que este negoçio queda en estado de que el cabildo puede contentarse porque la demonstraçión hecha no es pequeña, sin la que puede auer juntándose lo que resultare de la informaçión, la respuesta de Roma y lo que se presume querrá el General". Ningún fruto provendría de su permanencia en la corte para ninguno de los dos negocios que le ocupaban, el de los adjuntos y el de las coadjutorías, con el rey y sus ministros fuera de la misma, porque "el estar aquí más tiempo se auía de atribuir al negocio de Santiago, que no conbiene se entienda así". Por supuesto, no debía enviarse 
a otro en su lugar, y el mismo Caetani estaba de acuerdo con esta opinión. "Y Vuestra Señoría -insistía al cabildo- se asegure, que no todo lo que ay se dize passa por acá, porque ni Santiago ni don Gonzalo an traydo papeles de coadjutorías; y cuán çierto sea esto el tiempo lo manifestará y yo lo sé. No ay de qué tener cuidado, que en relaçión se sabe lo que basta y nada de ello es de consideraçión mas de para dar unos pocos de filos a los que tienen bien agudos contra la coadjutorías" ${ }^{70}$

Tal como deseaba, don Félix de Guzmán convenció a sus compañeros y volvió a Sevilla. El 5 de junio ya estaba en la ciudad y asistió a la reunión capitular que se celebró ese día en la que se estuvo discutiendo de nuevo acerca de las coadjutorías y se elaboró otro estatuto al respecto. ${ }^{71} \mathrm{La}$ cuestión iba a seguir su curso sin que se olvidara la persecución del osado fraile. El Nuncio cumplió su palabra y escribió a Roma anunciando "che uoleua mortificarlo" y, contra la específica recomendación de los dos Zapata, el memorial del cabildo contra Santiago llegó pronto a manos de la curia. Una vez recibido, el 25 de ese mes la Secretaría lo remitió por voluntad del mismo papa a Caetani "per reprimere l'ardire di detto frate, il quale è stato in questa corte et è molto ben conosciuto per huomo assai ben temerario et presuntuoso". ${ }^{72}$ Pero al mismo tiempo Roma estaba recibiendo noticias por otras vías de la actuación del arzobispo contra el cabildo y de las iniciativas de la junta gubernativa sobre las materias de adjuntos y coadjutorías que estaban agravando el conflicto jurisdiccional en Sevilla.

De modo inevitable, a lo largo de los meses siguientes estos conflictos, en los que subyacía esas razones de estado de las que hablaba Caetani a don Félix de Guzmán, y el tratamiento que había de darse al fraile mercedario fueron asuntos que se mezclaron en la correspondencia entre el Nuncio y el cardenal nepote. Después del primero, el cabildo envió a la curia un segundo memorial que estaba en manos de la Secretaría antes del 17 de agosto, fecha en la que ésta remitía nuevas instrucciones. En el mismo los capitulares solicitaban, primero, que el Papa hiciese que la nunciatura castigase a los culpables de haber ayudado a Santiago a huir de Madrid, una denuncia que contrastaba radicalmente con la que el Nuncio, como ahora se verá, daba del mismo hecho; y, en segundo lugar, que, para evitar mayores escándalos, obligase al racionero Gonzalo Mexía a que cumpliese la residencia de su prebenda; esto es, que abandonase la corte. El cabildo basaba

70 El don Gonzalo que menciona puede ser don Gonzalo del Campo el provisor o don Gonzalo Mejía, un racionero coadjutor que era el agente del arzobispo en Madrid (ver requerimiento del racionero Francisco Porras de la Cámara de 27 de octubre de 1614 en ACS, AA.CC., lib. 47, ff. 159v-160).

71 Ib., lib. 48, ff. 29v-31v.

72 Secretaría al nuncio, Roma, 25 de junio de 1615, ASV, NS, 339, 273. No obstante, no es la primera carta que se remitió sobre la cuestión. En la posterior de 1 de agosto Caetani menciona otra anterior de 21 de junio. 
su línea de defensa con el argumento de que el arzobispo no podía imponer a nadie que predicara en la catedral sin su consenso, un viejo motivo de fricción que ahora resurgía. Mexía, que no era racionero sino paradójicamente sólo coadjutor, había servido anteriormente como juez de testamentos en la curia de don Pedro de Castro y era el agente que éste había enviado a Madrid para hacerse oír ante la Junta de adjuntos. Por todas estas razones los prebendados veían ahora la oportunidad de eliminarlo del escenario. Pero el cardenal secretario, que veía las cosas con una perspectiva más amplia, optó por dejar en manos de la prudencia de Caetani lo que debía hacer respecto a esta última petición porque no querría abrir un nuevo frente de conflicto. Por el contrario, el Papa le ordenaba que llamase a "Picodoro», dejando a su albedrío someterlo a un castigo o simplemente corregirlo fraternalmente, pese a que, se decía repitiendo una opinión ya expresada, en Roma se sabía bien que se trataba de un hombre sedicioso, un sembrador de cizaña, que presumía de manejar la lengua con libertad y que ya en otras ocasiones había sido penitenciado por el Santo Oficio español. ${ }^{73}$

En el interim, antes de esta respuesta, Caetani había enviado al cardenal Borghese otras tres cartas. La tercera, fechada en Madrid el 1 de agosto, la dedicaba íntegramente a exponer la estrategia que había seguido en relación a fr. Hernando. ${ }^{74}$ De su lectura se desprende que el Nuncio había cumplido la palabra que le había dado al arcediano de Sevilla sin haberse dejado arrastar por las exigencias extremas de las reclamaciones que éste le había hecho llegar. Relataba a sus superiores todo lo que había hecho hasta entonces. Como buen diplomático, había procurado hacer compatible la mortificación del fraile por lo que había dicho sobre las coadjutorías en el púlpito sevillano, que calificaba de exorbitancias, con la prudencia que requería la temeridad de ese hombre y la calidad del delito. Para ello había hecho su propia investigación con la intención de tener un informe independiente al del cabildo. Había hecho que Santiago fuese a Madrid, donde lo había retenido los tres últimos meses con no poco sufrimiento de su parte porque se hallaba enfermo. Durante este tiempo había levantado el proceso y llegado a la conclusión de que las palabras del acusado pecaban de imprudencia más que de otra cosa. No le parecía conveniente abrir un juicio que podía terminar en manos de la Inquisición si prosperaba la denuncia que se le hacía de haber hablado contra la autoridad pontificia, dado que este hombre era "d'ingegno recalcitrante e inquieto" y tal vez haría todo lo posible para que así ocurriera. El problema radicaba en el método que debería seguirse para moderar tal ingenio, como había consultado con los generales de la Merced, el saliente y el entrante, con quienes

73 Secretaría a Caetani, Roma, 17 de agosto de 1615, ASV, NS, 339, 286/287.

74 Caetani al cardenal Borghese, Madrid, 1 de agosto de 1615, ib., 60 C, 342/343. Unas frases de esta carta ya fueron citadas por F. CORTINES, art. cit., p. 64, y Q. PÉREZ, op. cit., 157-158, y apéndice $V, n^{\circ} 3,195$. 
había tratado dos posibles soluciones. A Caetani le parecía mejor -más segura y sabia, decía- la primera, que consistía en encerrarlo en prisión perpetua en un convento. Esta opinión era compartida por los dos mercedarios, pero se desechó porque no había forma de asegurarse que no se fugase. Toda una confesión de la garantía de efectividad de tales medidas y también de la prevención que causaba un fraile tan libérrimo. Si la fuga llegara a producirse temían que su "talento di lingua e d'ingegno molto estraordinario" diera lugar a males mayores. La otra solución, la moderada, era tratarlo fraternalmente y esperar que pasase el tiempo, pues Santiago era un enfermo gotoso que estaba cerca de la vejez. Había otros remedios que otras veces se habían utilizado, afirmaba de una manera sibilina, mas no eran proporcionados a tal cerebro, de modo que había puesto en práctica el segundo. Siendo consciente de que a la curia debía de haber llegado ya la versión del cabildo sobre la fuga del fraile, el representante pontificio aseguraba que le había permitido volver a Sevilla para visitar a su anciana y moribunda madre y esperaba que se mantuviera callado y quieto con la amenaza de un castigo severo. ${ }^{75}$

Caetani terminaba su carta asegurando que en adelante fr. Hernando, porque era de esa clase de personas que no se podía contener ni dejar, si no se quería que turbase al resto de la República, viviría vigilado. Esta promesa fue cumpliéndola el Nuncio a lo largo de los meses siguientes, pero la solución tan benévola que había adoptado no fue del agrado de Roma. Borghese, cuyo recelo respecto lo que llamaba la presunción y arrogancia del mercedario había aumentado entretanto, no pudo ocultar su enfado cuando le contestó a vuelta de correo. Santiago, que era un "huomo di malissima intentione perche non andaua seminando se non zizanie fra persone grandi facendo spie doppie", merecía un castigo severo, que se le hubiese encarcelado y enviado preso a Roma. No obstante, las cosas estaban como estaban, y le aconsejaba que lo hiciera vigilar por personas de confianza para que no volviera a escaparse, una recomendación que daba a entender que se creyó más en las quejas del cabildo de Sevilla que a él mismo. Debía valerse de los remedios que le proponían los generales de la Orden para tenerlo controlado, bien que el medio más seguro era tenerlo en cárcel perpetua en un convento con las suficientes garantías de que no se fugase. ${ }^{76}$

75 Caetani decía que dos días antes de que le hubiese llegado la carta de la Secretaría de 21 de junio había tomado esta decisión. Pacheco, en su elogio, dice de fr. Hernando de Santiago que "fue piadosíssimo con su madre, i cuidava mucho de su salud; i desde Roma avisava cómo lo avían de regalar sus criados en tan luenga edad, en la cantidad i calidad de la comida. Solía dezir que la vida larga i los muchos peligros de que Dios le avía librado le procedía del bien que hizo a sus padres, i a su madre en su muerte, con un suntuosíssimo aplauso i con mucho onor, i con muchas missas que hizo dezir por su alma", Libro de descripción de los verdaderos retratos, 76-77.

76 Cardenal Borghese a Caetani, villa Mondragone, 7 de septiembre de 1615, ASV, NS, 339, 297. Esta carta la transcribe completa Q. Pérez, op. cit., apéndice V, no 4, 195-196, y cita parcialmente F. CORTINES, art. cit., 65. Ambos la fechan el 7 de agosto porque así la data el copista, pero es un error de éste. Se encuentra en la correspondencia de septiembre y, además, se refiere 
El 28 de septiembre un dolido Caetani respondió al cardenal nepote. En efecto, antes de que se lo hubiese sugerido, ya había destinado un informante a Sevilla para que observase los movimientos del fraile y hasta ahora, afirmaba, todo indicaba que el miedo lo mantenía quieto. Aunque creía que en el futuro continuaría con la misma cautela, temiendo la ruina que le sobrevendría si hacía lo contrario, también desconfiaba de que su inquietísimo carácter le llevase a mezclarse en nuevas complicaciones. El Nuncio terminaba diciendo que cumpliría lo que se le mandaba e insistiría en su vigilancia, pero, a modo de defensa, confesaba que él también pensaba que hubiese sido mejor tomar una medida más rigurosa si las cárceles españolas fuesen tan seguras como las italianas, a no ser que se le encerrase con sus mismos guardianes, y en cuanto a la reclusión en un convento, tenía éste y otros inconvenientes. ${ }^{77} \mathrm{Y}$ así debió de hacerse porque, después de la muerte de su madre, Caetani ordenó a fr. Hernando de Santiago que saliera de Sevilla. En agosto de 1616 Roma, al mismo tiempo que le felicitaba por ello, le animaba a perseverar en su control de tal manera que viviera marcado. ${ }^{78}$

Desde entonces se le impediría durante muchos años al célebre predicador que permaneciera en su ciudad natal. Pero allí donde estuviera, justificando los augurios que se hacían sobre su carácter, continuó defendiéndose de la acusación que le había lanzado el cabildo y sobre todo protagonizando nuevas iniciativas que provocaban, tanto a la nunciatura como a la curia pontifica, más dolores de cabeza. Es difícil explicar cómo se las arregló para hacer llegar un memorial a Paulo V en el que alegaba que él, contra lo que decían sus malévolos enemigos, no había predicado en aquel sermón que le había costado la persecución que los que daban y tomaban coadjutorías cometían simonía. ${ }^{79}$ Resulta sorprendente que la Secretaría atendiera su reclamación y ordenara a Antonio Caetani que tomase la provisión que considerase justa porque los informes contra su persona no cesaban de llegar a Roma. En enero de 1617 el cardenal secretario escribía, alarmado, que se maravillaba de que un hombre de aquella categoría -"un huomo de male qualità" - lograra, con el pretexto de que había inventado arbitrios para aumentar los ingresos de su hacienda, una audiencia con el rey sin que éste se disgustara. Había que conseguir que abandonara la corte cuanto antes. ${ }^{80}$ Más aún, en marzo Borghese volvía a aconsejar que encarcelara a Santiago para evitar que difundiera una sátira contra las coadjutorías y las formas de expedición de beneficios que se rumoreaba estaba escribiendo. ${ }^{81} \mathrm{Al}$ inquieto fraile se le veía en todas partes con su lengua dorada, fuese ejerciendo el arbitrismo ante el monarca, fuese debelando

claramente que es respuesta a la carta de Caetani de 1 de agosto.

77 Caetani al cardenal Borghese, Burgos, 28 de septiembre de 1615, ASV, NS, 60 D, 160.

78 Roma, 8 de agosto de 1616, ib., 340. 100/101.

79 Secretaría a Caetani, Roma, 7 de septiembre de 1616, ib., 340, 126/127.

80 Secretaría a Caetani, Roma, 14 de enero de 1617, ib, 340, 195.

81 Secretaría a Caetani, Roma, 22 de marzo de 1617, ib., 340, 223. 
la simonía y las corruptelas curiales. Sin embargo, en esta ocasión, al Nuncio le correspondió el papel de tranquilizar a las nerviosas autoridades romanas. No sabemos si lo consiguió cuando informó que esas incriminaciones había que atribuirlas a infundios de los numerosos enemigos que tenía "Picodoro» y que el acusado ni siquiera estaba ya en la corte, teniendo prohibido su estancia en ella. Además, el mismo general de la Merced creía que todas aquellas sospechas carecían de fundamento. ${ }^{82}$ Sobre esta base fr. Hernando debió creer que se reunían las condiciones para solicitar el perdón de la Santa Sede para poder regresar a Madrid y a Sevilla, su patria, ${ }^{83}$ pero todavía seguramente tuvo que ver como pasaba el tiempo antes de que se le concediera esta gracia.

La desaparición de la figura de fr. Hernando de Santiago del horizonte del cabildo catedral no desmiente el juicio que de su carácter emitió Caetani. En verdad que era un hombre tozudo e inquieto, nada propenso a cerrar la boca. El duro correctivo recibido por causa del sermón de la cuaresma de 1615 le obligó a callar, pero ni olvidó ni le hizo cambiar sus convicciones. Tampoco modificaría jamás su conducta, aunque fr. Marcos Salmerón entendiera el Acto de contrición que publicara en Sevilla, cinco ańos antes de su muerte, como "el estudio de un hombre muy desengañado" ${ }^{84}$ Sólo el miedo al castigo con que se le amenazó le llevó a guardar un prudente silencio soportado con la amargura a la que dio curso en el sermón que predicó en Granada en las honras por Felipe III. ${ }^{85}$ El cliente de esta pieza fue la misma ciudad y en ese momento el fraile era el comendador del monasterio de su orden, ${ }^{86}$ así que por mucho que el asunto de las coadjutorías le hubiese traído tantos sinsabores, su prestigio como predicador no se había visto afectado. Si se juzga por los textos que llevó a la imprenta, con este sermón su arte llegó a su cima. Como lo califica Herrero Salgado, no hizo "una oración fúnebre, sino un ataque furibundo contra validos y privados" ${ }^{87}$ Comentando a los Padres

82 En este sentido escribió Caetani al cardenal, Madrid, 30 de mayo de 1617, ib., 60 E, 225. El 7 de agosto contestaba la Secretaría aceptando la versión del nuncio pero indicando que, en caso contrario, se le aplicase al mercedario un "gran castigo", ib., 340, 267.

83 Es lo que pedía según escribía Borghese a Caetani, Roma, 8 de julio de 1617, ib., 340, 408.

84 Fr. Marcos SALMERÓN, Recuerdos históricos y políticos que de los servicios que los Generales y varones ilustres de Nuestra Señora de la Merced, Redención de Cautivos, han hecho a los Reyes de España, desde su gloriosa fundación, que fue el año de mil y doscientos diez y ocho hasta el años de mil y seiscientos quarenta; y desde el rey Don Iayme Primero de Aragón hasta Filipo Quarto Rey de las Españas, y Emperador de América, Valencia, en casa de los herederos de Chrysóstomo Garriz, por Bernardo Nogués, 1646, 411.

85 Fr. Hernando de SANTIAGO, Sermón que predicó el P. M. Fr. Hernando de Santiago, Comendador del Monasterio de nuestra Señora de la Merced. En las Onras que hizo la ciudad de Granada al señor Rei Filipo III, que santa gloria aya, en 15 de Maio de 1621. Dedicado al Reverendissimo Padre Gerónimo de Florencia, Predicador de su Magestad, Confessor de sus Altezas, Granada, por Bartolomé de Lorençana Ureña, 1621.

86 Lo era desde 1619, Q. PÉREZ, op. cit., 159.

87 Continúa "para él la muerte de Felipe III no fue ocasión de sermón, sino pretexto para un 
griegos, Nacianzeno y Crisóstomo, el gran patrono de su gremio y de quien se tomaba su propio apodo, explicaba en la dedicatoria la posición del orador eclesiástico, que era la suya, como reprensores de vicios y portavoces de la palabra divina, que no puede ser atada. Los que condenan al predicador carecen de jurisdicción porque éste ha sido hecho por el mismo Dios superior a los ángeles como decía San Pablo. Éste era su caso, aunque él no fuera el apóstol, "pero ni tanpoco Ángeles los censores de agora”, decía con desafío. Es fácil entender tal osadía y tanta valentía. Santiago comprendía perfectamente que la muerte del monarca representaba la ocasión de decir algunas de las cosas que había estado mascullando durante aquellos años de ostracismo, que, no obstante, no habían reducido en un ápice su autoestima. Que la impresión de la prédica que pronunció ante los granadinos la dedicara al predicador real, el jesuita Jerónimo de Florencia, demuestra que, pese a la imprudencia y la ligereza de palabra que en general se le atribuía, no carecía de sentido de la oportunidad, de olfato político. El papel del que llamaba "rei de los predicadores" en la caída de Lerma era bien conocido y las noticias sobre su posición al lado de un Felipe III moribundo ya se habían difundido. ${ }^{88} \mathrm{El}$ mercedario se lo dedicaba al jesuita porque creía que éste se hallaba víctima de una situación parecida a la suya, pues le ofrendaba el sermón porque "a començado a padecer lo que io por otros de esse estilo, de que sabe Dios que no estoi arrepentido i que buelto la ocasión repitiera lo dicho". ¿ Se refería al suyo sobre las coadjutorías y la simonía o a otros tanto o más comprometidos políticamente? En cualquier caso, no había arrepentimiento y si imprimía éste era porque no quería que se tergivesaran sus palabras y veía "que a llegado tienpo de podello dezir", y porque confiaba en que su destinatario influyera en los justos ministros, ya que "los que no lo son nunca e temido, ni ahora temo la indignación a los que podrán concitar sus dependentes aduladores".

Sin embargo, Florencia no se hallaba cerca de padecer lo que él había padecido ni, por lo que se sabe de su vida posterior, tampoco mostraba gran disposición a imitarlo. El jesuita, un predicador cortesano con ambiciones políticas, estaba en la intimidad del nuevo hombre fuerte en la corte, el conde de Olivares, y aún no se habría apagado la resonancia del sermón fúnebre que por el monarca fallecido

discurso político", op. cit., 355. Sobre este importante sermón, ib., 301-304, 351-355.

88 Ciriaco PÉREZ BUSTAMANTE, La España de Felipe III, Madrid, 1981, 155, 174, 193. La dedicatoria la reproduce F. HERRERO SALGADO, La oratoria sagrada en los siglos XVI y XVII. III. La predicación en la Compañia de Jesús, Madrid, 2001, 441. El juicio de Santiago sobre Jerónimo de Florencia como predicador era compartido por sus contemporáneos pero véase el veredicto duramente negativo de su persona y de su obra concionatoria de A. ASTRAIN, Historia de la Compañia de jesús en la Asistencia de España, Madrid, 1916, Tomo V, 216-217. Herrero Salgado, aunque se muestra de acuerdo en líneas generales con el historiador jesuita, reconoce su habilidad retórica y calidad literaria, opinión que han mantenido otros especialistas, La oratoria sagrada. III, 442-443, 471. 
había pronunciado el 4 de mayo ante el joven Felipe IV y el estrenado valido, una auténtica proclama a favor del valimiento del nuevo astro ascendente. ${ }^{89}$ Santiago, por el contrario, que predicó el 21 de mayo, orientó el suyo en un sentido contrario, pues, por mucho que todo el mundo entendiera que el objeto de sus iras fuese el cardenal-duque, se trataba de un formidable ataque contra los privados. Y con ello daba pie a que cualquiera que conociera su obra anterior tuviese motivos para admirarse porque fr. Hernando no había pensado siempre como ahora se manifestaba. Sin variación, sus Consideraciones sobre los Evangelios de los Santos estuvieron dedicadas al duque de Lerma y, aunque en la portada de la primera edición figuraban las armas del valido y en la última éstas habían sido sustituidas por una estampa de la Virgen con el Nińo en brazos, la dedicatoria, plenamente circunscrita a las reglas del panegírico ilimitado, se conservaba. Se supone, por tanto, que no cambió durante estos años su concepción de la privanza como para arrepentirse de haber colocado su libro bajo la protección de quien, siguiendo sus propias palabras, reunía en su persona el cordero, en lugar de la zorra maquiaveliana, y el león, la suavidad y la blandura con el poder.

La modificación de su opinión debió de producirse, por tanto, desde mediados de 1615, cuando comenzó a verse perseguido por su sermón sevillano. No era necesario ser un malpensado para suponer que detrás de su actitud actual había acaso motivos personales, el sentimiento de haberse visto abandonado en aquella circunstancia tan aciaga para él. En los ańos que separan el anodino sermón que pronunciara por Felipe II en Málaga en 1598 de éste, motivado por las honras del hijo, fr. Hernando debió de ir evolucionando su técnica y su contextura ideológica hasta llegar a su madurez como predicador político. Sólo hay que hacer una salvedad; había llegado el tiempo de poder hablar y ahora no se corría ningún riesgo en hacerlo, de manera que su feroz crítica del valimiento se añade a un estado de opinión más general. Para exponerla escogió un versículo de Oseas como tema. ${ }^{90}$ La elección de una imprecación divina tan transparente y de un profeta de la destrucción y la ruina es de por sí suficientemente explícita, si bien se permitió una licencia. Felipe III no era Jeroboán, un usurpador y tirano, sino un rey santo, literalmente, que reinó engañado por privados que lo rodearon de

89 Para la intimidad de Jerónimo de Florencia con Olivares en esta época y su contribución a su ascenso al poder, J. H. ELLIOTT, El Conde-duque de Olivares. El político en una época de decadencia, Barcelona, 1990, 67. Sobre la orientación de su sermón del 4 de mayo, Antonio FEROS, El duque de Lerma. Realeza y privanza en la España de Felipe III, Madrid, 2002, 468. Un análisis del Sermón que predicó a la majestad católica del rey don Felipe Quarto, Madrid, Luis Sánchez, 1621, en F. HERRERO SALGADO, La oratoria sagrada. III, 452-465. Sobre el personaje, más recientemente, Jerónimo GARAU, «Notas para una biografía del predicador real Jerónimo de Florencia (15651633)», Revista de Literatura, vol. LXVIII, no 135 (2006, enero-junio), 101-122.

90 «Transire fecit Samaria regem suum, quasi spumam super faciem aquae. Et dispergentur (sic: disperdentur) excelsa idoli, peccatum Israel», Oseas, 10: 7-8. 
fiestas y lo entretuvieron con mentiras para alejarle de los grandes, de las personas de autoridad, de los predicadores y de todo aquel que pretendiera acercársele para proclamar la verdad. Si el pecado de Israel fueron los ídolos, en la monarquía no eran ídolos contra la religión, cosa imposible en un Reino tan católico, sino del interés. Los privados se hicieron riquísimos mientras que el monarca era pobre y el mismo Reino quedaba exahusto. ${ }^{91}$

Ante su público granadino el mercedario desplegó una crítica que no se ciñó a unos términos morales. Incluso, una vez más, pudo rebasar los límites de la prudencia que le convenían porque con dificultades el sentido de su oración sería adecuado a la dirección de los vientos que corrían en la corte. Por supuesto poco casaba con las ideas que había expresado el P. Florencia, a no ser que se interpretara convenientemente una de sus máximas: "Tengamos lástima a los Reies que siempre viuen en duda sin poderse asegurar de quien priua i gobierna”. Es decir, si se entendiera que el nuevo rey podría estar seguro del privado que se esperaba, porque Santiago preconizaba una política de reputación. ${ }^{92}$ Ésta sería la contraria de la que él había sido testigo y que pudo haberse encauzado si los ministros del santo rey difunto no le hubieran aconsejado hacer paces "con los Estados rebeldes, enemigos de la Iglesia, i tomar medios i composición con los iudíos de Portugal". ${ }^{3}$

Su sermón concluía con una llamada a superar la política pacifista de Lerma. Veía a toda la Iglesia y a sus clérigos convertidos en soldados en pos de un rey que se arrojase en manos de Dios. La validez de una política decidida y providencialista que ejemplificaba con el éxito de la iniciativa contra Venecia del conde de Benavente, virrey de Nápoles, y del conde de Fuentes, gobernador de Milán, en ayuda de la Santa Sede, un hecho del que se sentía orgulloso por haberse hallado entonces en Italia al lado de sus protagonistas. Toda la responsabilidad de los errores de Felipe III recaía así sobre sus ministros; pecado de Israel y no del rey, purgadas su penas por sus grandes servicios a Dios y a la Iglesia. Éstos habían sido la expulsión de seiscientos mil "medio moros i otros enteros" de Castilla y Aragón, pese a "tan gran menoscabo de su Real Patrimonio", y los ingentes gastos hechos para detener al Turco, para apoyar en Alemania a los católicos contra los herejes, y para procurar en Roma la elección de un papa santo. Sus fracasos inevitablemente habían sido consecuencia del latrocinio de la hacienda real hecho por unos consejeros idólatras y de la desconfianza en la ayuda divina. Toda una lección para el presente.

91 Sermón..., ff. 3-4v.

92 Desarrolla esta idea en la tercera de las cuatro "consideraciones" en que dividió el sermón.

93 Referencia obvia a la Tregua de 1609 con los holandeses y al asiento negociado con los hombres de negocios portugueses en 1605 a cambio de una licencia para que 10.000 judíos vivieran en lugares señalados según se hacía eco Cabrera de Córdoba, en Julio CARO BAROJA, Los Judíos en la España Moderna y Contemporánea. II, Madrid, 2a edición, 1978, 49. 
